\title{
Grazing cows are more efficient than zero-grazed and grass silage-fed cows in milk rumenic acid production
}

\author{
R. Mohammed, ${ }^{*}$ C. S. Stanton, † J. J. Kennelly, ${ }^{* 1}$ J. K. G. Kramer,ł J. F. Mee,† D. R. Glimm, ${ }^{*}$ M. O’Donovan,† \\ and J. J. Murphy† \\ ${ }^{*}$ Agricultural, Food and Nutritional Science, University of Alberta, Edmonton, Alberta, Canada \\ †Teagasc, Dairy Production Research Centre, Moorepark, Co. Cork, Ireland \\ $\ddagger$ Agriculture and Agri-Food Canada, Guelph Food Research Centre, Guelph, Ontario, Canada
}

\section{ABSTRACT}

Six rumen-cannulated Holstein cows in early lactation were assigned to 3 treatments: grazing $(\mathrm{G})$, zerograzing $(\mathrm{ZG})$, and grass silage (GS) harvested from the same perennial rye grass sward in a $3 \times 3$ Latin square design with three 21-d periods. The objectives of this study were to investigate the underlying mechanisms for the reported elevation in milk rumenic acid (RA) concentration associated with G compared with ZG and GS, and to identify the important variables contributing to the milk RA response. Grazing animals were offered $20 \mathrm{~kg}$ of dry matter/cow per day; indoor animals were offered ad libitum grass or silage. A concentrate at a rate of $3 \mathrm{~kg} / \mathrm{d}$ was also offered to all cows. Rumen, plasma, and milk samples were collected in the third week of each period. Data were analyzed by the MIXED procedure of SAS. Dry matter intakes were less for GS with no difference between $G$ and $Z G$. Milk yield was greater for $\mathrm{G}$ than for ZG or GS. Milk fat and protein contents were less for GS with no difference between $\mathrm{G}$ and ZG. The combined intake $(\mathrm{g} / \mathrm{d})$ of linoleic and linolenic (18:3n-3) acids was different across the treatments (G: 433; ZG: 327; and GS: 164). Rumen $\mathrm{pH}$ was less for $\mathrm{G}$ with no difference between ZG and GS. Concentrations of volatile fatty acids and ammonia nitrogen in rumens were not different across the treatments. Wet rumen fill was less for $G$ with no difference between ZG and GS. Vaccenic acid concentrations were different across the treatments in rumen (G: $12.30 \%$, ZG: $9.31 \%$, and GS: $4.21 \%$ ); plasma (G: $2.18 \%, \mathrm{ZG}: 1.47 \%$, and GS: $0.66 \%$ ) and milk (G: $4.73 \%$, ZG: $3.49 \%$, and GS: $0.99 \%$ ). Milk RA concentrations were greater for $\mathrm{G}(2.07 \%)$ than for ZG (1.38\%) and GS $(0.54 \%)$. Milk desaturase index based on the ratio cis-9-14:1/14:0 was not different across the treatments. Milk RA yield per $100 \mathrm{~g}$ of linoleic acid and linolenic

Received August 8, 2008.

Accepted March 17, 2009

${ }^{1}$ Corresponding author: john.kennelly@ualberta.ca acid intake (efficiency) was 2.23, 1.50 , and $0.62 \mathrm{~g}$ in $\mathrm{G}, \mathrm{ZG}$, and GS, respectively, suggesting that $\mathrm{G}$ cows were more efficient than ZG and GS cows in milk RA production. Stepwise regression analysis of a group of variables revealed that plasma vaccenic acid accounted for $95 \%$ of the variation in milk RA production. Milk desaturase index did not enter into the model. Overall findings suggest that substrate intake influenced milk RA production but it was not the only factor involved. There were differences in efficiency of milk RA production, which appears to depend on the factors regulating ruminal vaccenic acid production and its supply to the mammary tissue.

Key words: rumenic acid, vaccenic acid, conjugated linoleic acid, grazing

\section{INTRODUCTION}

Rumenic acid (RA) is a component of milk fat with demonstrated health benefits. Biosynthesis of milk RA requires a source of polyunsaturated fatty acid (PUFA) substrate such as linoleic acid (LA) and linolenic acid (LNA) in the feed that is biohydrogenated in the rumen supplying a combination of precursor, vaccenic acid (VA), and small amounts of product (RA) to the mammary gland (Bauman et al., 1999). The extent of ruminal biohydrogenation of PUFA in turn has been reported to be influenced by the initial concentration of dietary LA (Harfoot et al., 1973), passage rate, and rumen $\mathrm{pH}$ (Martin and Jenkins, 2002; TroegelerMeynadier et al., 2003; Qiu et al., 2004). In the mammary tissue, most of the RA is formed from VA by the action of $\Delta^{9}$-desaturase (Griinari et al., 2000). Thus biosynthesis of milk RA is dependent on the amount of substrate in feed, the extent of biohydrogenation in the rumen, and the desaturase activity of the mammary tissue. Although the significance of the above 3 factors on milk RA concentrations is well known, the relative contribution of each has not been established.

Fresh grass is a rich source of LNA. However, its concentration varies with growth stage and the form 
in which it is fed. Chilliard and Ferlay (2004) reported that milk RA response varies among forages, with fresh grass $>$ hay $>$ maize silage $>$ grass silage. Moreover, pasture (grazing) and barn (zero-grazing) feeding, which is feeding fresh grass outdoors and indoors, respectively, has been reported to influence milk RA response differently (Leiber et al., 2005). Offer (2002) and Elgersma et al. (2003) found that beneficial fatty acids (FA) including RA were greater in milk for grazed animals than for zero-grazed grass or grass silage.

The present study was designed to investigate possible mechanisms underpinning the differences in milk RA concentrations and yields among cows grazing $(\mathbf{G})$, zero-grazing (ZG), or fed grass silage (GS) with the following objectives: 1) to determine the supply of substrate from the different diets; 2) to investigate if offered and consumed grass by grazing cows differed in substrate content; 3) to determine the effect of the diets on rumen environment; 4) to gain an understanding of the biosynthesis of milk RA by evaluating the FA composition of feed, rumen ingesta, plasma and milk with specific interest in VA and RA; 5) to investigate if there were treatment differences in the efficiency of milk RA production; and 6) to identify the most important variables contributing to the differences in milk RA.

\section{MATERIALS AND METHODS}

\section{Experimental Design and Treatments}

All procedures were carried out under license in accordance with the European Community Directive 86-609-EC. Six spring-calving, rumen-cannulated, multiparous (lactation number 2 to 5) Holstein-Friesian dairy cows in early lactation (average milk yield 21.9 $\pm 4.8 \mathrm{~L} / \mathrm{d}$; average DIM $76 \pm 18 \mathrm{~d}$; average BW of 542 $\pm 34 \mathrm{~kg}$ ) were balanced for milk yield and DIM and assigned to 2 squares. Within a square, the animals were randomly assigned to 3 treatments: grazed grass, zero-grazed grass, and grass silage in a $3 \times 3$ Latin square design with three 21 -d periods. Cows received 3 $\mathrm{kg} / \mathrm{d}$ per cow of concentrate supplement. The experiment was undertaken between June and August on a perennial ryegrass sward at the Dairy Production Research Centre, Moorepark, Ireland (55 $\left.10^{\prime} \mathrm{N}, 8^{\circ} 16^{\prime} \mathrm{W}\right)$. All the experimental animals were grazing a perennial ryegrass sward before the feeding experiment. Silage was harvested from the same perennial ryegrass sward, field-wilted for $2 \mathrm{~h}$, and baled in bags in May.

\section{Management of Grazing Cows}

A grazing area of 1.7 ha consisted of 2 main grazing blocks. These were subdivided into 2 equal halves to offer grass for G or ZG animals. Paddock area utilized for the study was divided width-wise in such a way that the $\mathrm{G}$ and $\mathrm{ZG}$ cows received the same quality of grass throughout the experiment. Grass cuts (GC) were taken twice weekly (at $4 \mathrm{~cm}$ from the ground) to determine the herbage mass by cutting 2 strips $(1.2 \times 10 \mathrm{~m})$ with a motor Agria (Etesia UK Ltd., Warwick, UK). Ten grass height measurements were recorded before and after harvesting on each cut strip using an electronic plate meter (Urban and Caudal, $1990)$ with a plastic plate $(30 \times 30 \mathrm{~cm}$ and $4.5 \mathrm{~kg} /$ $\mathrm{m}^{2}$; Agro Systemes, Choiselle, France). This allowed us to determine the sampled height precisely and allowed the calculation of the sward density [DM per hectare divided by the precutting height minus the postcutting height ( $\mathrm{kg}$ of $\mathrm{DM} / \mathrm{cm}$ per ha)]. All mown herbage from each strip was collected and weighed, and a representative sample (300 g) was retained. A 100-g subsample of the herbage was dried overnight at $90^{\circ} \mathrm{C}$ in an oven for DM determination. The remaining $200 \mathrm{~g}$ of the herbage collected from the 2 strips was bulked, subsampled $(\sim 100 \mathrm{~g})$, and stored at $-20^{\circ} \mathrm{C}$. Pregrazing and postgrazing sward heights were recorded daily by taking measurements across the diagonals of the grazed strip. The measured pregrazing sward height multiplied by the mean sward density was used to calculate the daily herbage allowance of the grazing animals. Grazing cows were strip-grazed through each half of the 2 blocks to offer $20 \mathrm{~kg}$ of $\mathrm{DM} / \mathrm{cow}$ per day. Electric fences were used for strip-grazing and were moved once daily with a back fence so that the cows did not have access to the area already grazed. A concentrate containing rolled barley $(300 \mathrm{~g} / \mathrm{kg})$, citrus pulp $(460 \mathrm{~g} / \mathrm{kg})$, soybean meal $(180 \mathrm{~g} / \mathrm{kg})$, soybean oil $(30 \mathrm{~g} / \mathrm{kg})$, and mineral/vitamin mix $(30 \mathrm{~g} / \mathrm{kg})$ was offered to all cows at a rate of $3 \mathrm{~kg} / \mathrm{d}$ before the evening milking.

Individual intakes for the grazing cows were measured using a controlled release n-alkane marker [Alkane CRC, Captec (NZ) Ltd., Auckland, New Zealand] in each period. For each animal, one alkane bullet was introduced into the rumen through the cannula on $\mathrm{d}$ 7. Herbage snip (HS) samples (approximately $500 \mathrm{~g}$ in polythene bags), which closely represented the herbage that the cows were selecting, were collected daily from $\mathrm{d} 7$ following the introduction of the bullet for a period of $6 \mathrm{~d}$ and stored at $-20^{\circ} \mathrm{C}$. Fecal grab samples (approximately $250 \mathrm{~g}$ ) were collected twice daily for 7 $\mathrm{d}$ from $\mathrm{d} 8$ following the introduction of the bullet and stored at $-20^{\circ} \mathrm{C}$ until analysis. The HS were freezedried, milled, and analyzed individually. The fecal grab samples of each grazing cow from the total collection period were bulked to obtain one sample per cow per period. This was dried for $48 \mathrm{~h}$ at $40^{\circ} \mathrm{C}$, milled, and analyzed. The n-alkane concentration in HS and feces 
was determined following the method described by Mayes et al. (1986).

\section{Management of Indoor Cows}

Cows were housed in tie-stalls with water available at all times. Indoor cows were offered ad libitum grass or silage. The intakes were adjusted to have at least 5 to $10 \%$ of weigh-backs. Grass offered to the ZG animals was cut twice daily at $4 \mathrm{~cm}$ from the ground with an Agria motor. Offered and refused grass and silage samples were collected twice daily from the indoor-fed cows during the experimental period and DM intakes calculated. Concentrate feeding was the same as for the G cows.

\section{Sampling and Chemical Analyses}

Samples of grass offered to the grazing cows were collected twice weekly from GC (4 cm from the ground) and combined into one sample per week. Forage samples for the indoor cows (ZG and GS) were collected daily (a.m. and p.m.). Both morning and evening samples offered to ZG and GS were bulked by treatment on a weekly basis to obtain 3 samples per treatment per period. All the forage samples collected were freeze-dried and ground through a 1-mm screen using a Wiley mill (Thomas-Wiley, Philadelphia, PA). Samples were analyzed for DM content (at $135^{\circ} \mathrm{C}$ for $2 \mathrm{~h}$ ), ash (overnight at $550^{\circ} \mathrm{C}$ ), ADF, NDF (Ankom filter bag technique with the reagents sodium sulfite and $\alpha$-amylase; Van Soest et al., 1991), and nitrogen content (multiplied by 6.25 for determination of $\mathrm{CP}$ using Leco nitrogen combustion analyzer; Leco Corporation, St. Joseph, MI). For the grazing cows, HS were collected $(4 \mathrm{~cm}$ from the ground) in wk 3 of each period for 6 consecutive days. These samples were freeze-dried, milled, and combined to obtain one sample per period representing consumed grass for the grazing cows. Herbage snips were collected by following each cow at different points within the paddock and collecting grass samples (4 $\mathrm{cm}$ from ground) using a hand-held grass cutter. The concentrate fed was sampled once per period. The combined forage samples from wk 3 of each period and the concentrate from the respective period were utilized for FA analysis. Total lipids from the forage and concentrate samples were extracted with chloroform/methanol (1:1) along with an internal standard (23:0) and methylated with methanolic HCl. The fatty acid methyl esters (FAME) obtained were purified by thin layer chromatography (TLC) using hexane/diethyl ether/acetic acid (85:15:1) and then analyzed by GLC. The FA contents of forage and concentrate were determined from the quantity of the sample analyzed relative to the internal standard.
The product of forage DM intake and the forage FA content gave the forage FA intake. Likewise, the FA intake from the concentrate supplement was also calculated. Total FA intake of individual animals was determined from the sum of the forage and concentrate FA intake. Linoleic acid and LNA intakes were estimated from the product of the proportions of the respective FA from the total DMI with the total FA intake. Total substrate intake was determined by summing LA and LNA intake.

Rumen sampling was done morning (before feeding) and afternoon (6 h after morning feed) on d 18 and 19. Rumen samples were collected from the dorsal, ventral, cranial, and caudal regions of the rumen in 2 sterilized $250-\mathrm{mL}$ containers with air-tight lids. One of the containers was stored at $-20^{\circ} \mathrm{C}$ for $\mathrm{FA}$ determination, and the contents from the other were passed though a cheesecloth and stored frozen in six 14-mL Falcon tubes. Two tubes were utilized for recording $\mathrm{pH}$ immediately after collection using a $\mathrm{pH}$ meter fitted with a glass electrode (Radiometer, Copenhagen, Denmark), and the other 4 tubes were stored at $-20^{\circ} \mathrm{C}$ until utilized for VFA and ammonia nitrogen analysis following the procedures of Ranfft (1973) and Short (1954), respectively. Wet rumen fill was recorded on the final day (d 21) of each period by evacuating and weighing the total rumen contents. Dry matter content of a representative sample was measured and used to calculate rumen DM fill. After collecting the samples, the whole contents were placed back into the animal's rumen.

Rumen samples for FA determination were freezedried and milled. The samples collected on d 18 and 19 were pooled and about $0.5 \mathrm{~g}$ of the pooled samples was utilized for FA analysis following the protocol described by Or-Rashid et al. (2008). The hexane extract obtained following methylation (with TMS-diazomethane; TCI America, Portland, OR) was condensed to about 100 $\mu \mathrm{L}$ under a stream of $\mathrm{N}_{2}$ and applied to a silica gel-G plate (Fisher Scientific, Ottawa, Ontario, Canada). The TLC plate was developed using the solvent hexane/ diethyl ether/acetic acid (in the ratio 85:15:1 vol/vol/ vol) and visualized with 2',7'-dichlorofluorescein under UV light. The FAME band was scraped off the TLC plate and extracted using hexane for analysis by GLC.

Blood was collected from the coccygeal vessels in heparinized vacutainers at the same time as the rumen was sampled in the morning and evening of $\mathrm{d} 18$ and 19 of each period. Collected blood samples were placed on ice immediately and centrifuged within $1 \mathrm{~h}$ of collection at $4^{\circ} \mathrm{C}$ for $30 \mathrm{~min}$ at $3,000 \times \mathrm{g}$. Plasma was harvested and stored at $-20^{\circ} \mathrm{C}$ until analysis. The 2 a.m. and 2 p.m. samples were pooled animal-wise and utilized for lipid extraction. Plasma lipids were extracted using a modification of the Bligh and Dyer procedure as 
described by Cruz-Hernandez et al. (2004). Total lipids extracted from $1 \mathrm{~mL}$ of plasma were divided into 2 aliquots for acid-catalyzed and base-catalyzed methylation procedures, respectively, as described by Kraft et al. (2008). In brief, base-catalyzed methylation was performed using $0.5 \mathrm{~mL}$ of $0.5 \mathrm{~N} \mathrm{NaOCH}_{3} /$ methanol (Supelco Inc., Bellefonte, PA) for $30 \mathrm{~min}$ at $50^{\circ} \mathrm{C}$; and acid-catalyzed methylation was performed using 0.5 $\mathrm{mL}$ of $5 \% \mathrm{HCl}$ gas in anhydrous methanol (wt/vol) for $1 \mathrm{~h}$ at $80^{\circ} \mathrm{C}$. The results obtained from both methylation procedures were used in combination (Kraft et al., 2008; Kramer et al., 2008) to overcome the limitations of each methylation procedure. The acid-catalyzed methylation procedure facilitated the identification of dimethyl acetals (DMA) in addition to FAME. The methylation products obtained were purified by TLC on silica gel G plates using n-hexane/diethyl ether/ acetic acid (85:15:1) as developing agent. The TLC band containing FAME and DMA that coeluted were identified using a TLC standard containing FAME, triacylglycerol, free cholesterol, cholesteryl ester, and free FA (\#18-4A, Nu-Chek Prep Inc., Elysian, MN) after spraying the plates with 2',7'-dichlorofluorescin $(0.01 \% \mathrm{wt} / \mathrm{vol})$ in methanol and visualizing under UV light at $254 \mathrm{~nm}$. The FAME/DMA band identified was scraped off the TLC plate and extracted using $5 \mathrm{~mL}$ of chloroform, dried under $\mathrm{N}_{2}$, and resuspended in nhexane for GLC analysis. The derivatization products were analyzed using 2 different temperature programs as described by Kramer et al. (2008).

Milk yield was recorded daily. Milk sampling was done twice (a.m. and p.m.) on d 18 and 19 of each period. The a.m. and p.m. samples were pooled for each cow on each sampling day in proportion to the morning and evening milk yields. Milk samples from the 2 consecutive days were again pooled in proportion to the daily yields and divided into 2 aliquots. One aliquot was preserved with potassium dichromate and analyzed for protein, fat, and lactose using a Milkoscan 203 (Foss Electric DK-3400, Hillerød, Denmark). The second aliquot was stored at $-20^{\circ} \mathrm{C}$ until analyzed for milk FA composition using GLC. Milk lipids were extracted using a chloroform/methanol/water (2:2:1.8) mixture at a 20:1 solvent to sample volume ratio and methylated using $\mathrm{NaOCH}_{3} /$ methanol (Cruz-Hernandez et al., 2004). The FAME were analyzed using a Hewlett Packard Model 5890 Series II GLC equipped with a flame-ionization detector, an autosampler (HP Model 7673), a 100-m CP-Sil 88 fused capillary column (Varian Inc., Mississauga, Ontario, Canada), and software program (Agilent ChemStation, Version A.10) and operated in a splitless mode that was flushed $0.3 \mathrm{~min}$ after injection. Injector and detector temperatures were kept at $250^{\circ} \mathrm{C}$. Hydrogen was used as carrier gas at a flow rate of $1 \mathrm{~mL} / \mathrm{min}$ and for the flame-ionization detector at $40 \mathrm{~mL} / \mathrm{min}$. Other gases used were purified air at $250 \mathrm{~mL} / \mathrm{min}$ and $\mathrm{N}_{2}$ makeup gas at $25 \mathrm{~mL} /$ min. The injection volume was $1 \mu \mathrm{L}$ of FAME mixtures containing about $1 \mu \mathrm{g} / \mu \mathrm{L}$. The FAME obtained from each milk sample were analyzed using 2 temperature programs $\left(175^{\circ} \mathrm{C}\right.$ and $\left.150^{\circ} \mathrm{C}\right)$ as described by Kramer et al. (2008). The FAME were identified by comparison with a GLC reference standard (\#463) spiked with a mixture of 4 positional conjugated linoleic acid (CLA) isomers (\#UC-59M), 21:0, 23:0, and 26:0 obtained from $\mathrm{Nu}-\mathrm{Chek}$ Prep Inc. Identification of 16:1, 18:1, and 20:1 isomers was based on available isomers in the GLC reference standard (\#463), comparison with published reports, and based on principles of silver-ion separation. Confirmation of 18:1 isomers was made using $\mathrm{Ag}^{+}$-solid phase extraction separated fractions as described by Kramer et al. (2008). Individual FAME were reported as a percentage of total FAME.

\section{Statistical Analysis}

Feed FA data were analyzed using the GLM procedure of SAS (version 9.1.3, SAS Institute Inc., Cary, NC). Dry matter intakes, LA and LNA intake, efficiency of milk RA production, milk yield, composition, rumen $\mathrm{pH}$, VFA, ammonia concentrations, and FA data from rumen, plasma, and milk were analyzed using the MIXED procedure of SAS (version 9.1, SAS Institute) with treatment as the fixed effect; square, period, and cow (square) as random effects. Differences among least squares means were declared significant when the $P$ value was $<0.05$. Trends were discussed when $0.05 \geq$ $P<0.1$. The model used for the analysis was $\mathrm{Y}_{\mathrm{ijkl}}=$ $\mu+\mathrm{T}_{\mathrm{i}}+\mathrm{P}_{\mathrm{j}}+\mathrm{S}_{\mathrm{k}}+\mathrm{C}(\mathrm{S})_{1}+\mathrm{e}_{\mathrm{ijkl}}$, where $\mathrm{Y}_{\mathrm{ijkl}}$ is the observation, $\mu$ is the overall mean, $T_{i}$ is the fixed effect of treatment, $\mathrm{P}_{\mathrm{j}}$ is the random effect of period, $\mathrm{S}_{\mathrm{k}}$ is the random effect of square, $\mathrm{C}(\mathrm{S})_{1}$ is the random effect of cow within square, and $\mathrm{e}_{\mathrm{ijkl}}$ is the residual error. The relationship between milk RA yield and source of substrate ( $\mathrm{GC}$ or $\mathrm{HS}$ ) for $\mathrm{G}$ cows was investigated using the REG procedure of SAS. Stepwise regression analysis was used to identify the variables that most influenced milk RA yield with multiple factors using STEPWISE procedure of SAS. The threshold value to keep a term in the model was $P \leq 0.09$.

\section{RESULTS AND DISCUSSION}

Grass silage is rarely offered as the sole feed to lactating dairy cows because the DM intakes are generally too low to provide adequate nutrients. However, in this study the cows were past peak milk production and the silage was supplemented with $3 \mathrm{~kg}$ of concentrate 
Table 1. Chemical composition of the experimental diets and concentrate supplement

\begin{tabular}{|c|c|c|c|c|}
\hline \multirow[b]{2}{*}{ Item } & \multicolumn{3}{|c|}{ Diet } & \multirow{2}{*}{$\begin{array}{l}\text { Concentrate } \\
\text { supplement }\end{array}$} \\
\hline & Grazed grass $^{2}$ & Zero-grazed grass & Grass silage & \\
\hline DM, \% & 17.9 & 18.2 & 22.9 & 88.6 \\
\hline $\mathrm{CP}, \%$ & 24.1 & 19.8 & 12.1 & 21.8 \\
\hline Total fat, ${ }^{3} \%$ & 4.1 & 3.3 & 1.9 & 1.9 \\
\hline NDF, \% & 41.5 & 45.4 & 50.8 & 21.6 \\
\hline ADF, $\%$ & $\mathrm{ND}^{4}$ & 25.5 & 30.1 & 9.2 \\
\hline Ash, $\%$ & 8.7 & 9.4 & 7.4 & 8.7 \\
\hline $\mathrm{NE}_{\mathrm{L}}, \mathrm{Mcal} / \mathrm{kg}$ & ND & 1.5 & 1.5 & ND \\
\hline
\end{tabular}

${ }^{1}$ Concentrate supplement containing rolled barley, $30 \%$; citrus pulp, $46 \%$; soybean meal, $18 \%$; soybean oil, $3 \%$; and mineral/vitamin mix, $3 \%$ was offered to all cows at $3 \mathrm{~kg} / \mathrm{d}$.

${ }^{2}$ Chemical composition of the herbage snips (consumed grass for grazing cows). The DM, CP, total fat, NDF, and ash content in grass cuts (representative of offered grass for grazing cows) were 18.6, 20.4, 3.1, 46.4, and $12.9 \%$, respectively.

${ }^{3}$ Determined by GLC and expressed as triglycerides.

${ }^{4} \mathrm{ND}=$ not determined.

per day. In practice, cows offered grass at this stage of lactation would not normally receive concentrate supplement, but to avoid any confounding effects, cows on $\mathrm{G}$ and $\mathrm{ZG}$ also received the same supplement at 3 $\mathrm{kg} / \mathrm{d}$.

\section{DMI, Milk Yield, and Composition}

Nutrient composition of the forages is presented in Table 1 and the values would be typical for these forages in Ireland. The lesser DM intake for GS compared with G (Table 2) was anticipated because previous studies have shown that voluntary intake of forage DM when conserved as silage is lower than that of the herbage from which it was produced (Harris et al., 1966; Demarquilly, 1973). Silage in the current study was harvested after 5 wk of growth, whereas cows on $G$ and ZG were offered grass that was about 3 wk old. The differences in the growth stage and the higher fiber content in GS compared with G and ZG, indicative of lower digestibility, could also have contributed to the lower intake of GS.

Milk yield was greater for $\mathrm{G}$ than for ZG by $22 \%$, which in turn was greater than for GS by $25 \%$. The difference in the average milk yield between G and GS reflects the difference in total DMI between these treatments. Milk yield was greater for $\mathrm{G}$ than $\mathrm{ZG}$, but forage DMI and total DMI were not different between $G$ and ZG. The higher milk yields for $G$ animals compared with ZG could be partly because of the opportunity for selective grazing for $G$ cows. Grazing cows can more readily reject unsuitable forage and preferentially consume the leafy and more easily digestible portions of the grass compared with ZG cows. Consistent with this, higher OM digestibility (Morgan et al., 1989) was observed in G (HS or consumed grass: $83.9 \%$; GC or offered grass: $79.1 \%$ ) compared with ZG (80.3\%). Similar differences in the milk yields between $\mathrm{G}$ and ZG were

Table 2. Dry matter intake, milk yield, and milk composition

\begin{tabular}{|c|c|c|c|c|c|}
\hline \multirow[b]{2}{*}{ Item } & \multicolumn{3}{|c|}{ Diet $^{1}$} & \multirow[b]{2}{*}{$P$-value } & \multirow[b]{2}{*}{ SEM } \\
\hline & G & $\mathrm{ZG}$ & GS & & \\
\hline Forage DMI, kg/d & $16.1^{\mathrm{a}}$ & $15.3^{\mathrm{a}}$ & $13.0^{\mathrm{b}}$ & 0.02 & 0.60 \\
\hline Total DMI, kg/d & $18.7^{\mathrm{a}}$ & $17.9^{\mathrm{a}}$ & $15.6^{\mathrm{b}}$ & 0.02 & 0.60 \\
\hline Total forage fatty acid intake, $\mathrm{kg} / \mathrm{d}$ & $0.6^{\mathrm{a}}$ & $0.5^{\mathrm{b}}$ & $0.2^{\mathrm{c}}$ & $<0.01$ & 0.02 \\
\hline Total fatty acid intake, $\mathrm{kg} / \mathrm{d}$ & $0.7^{\mathrm{a}}$ & $0.5^{\mathrm{b}}$ & $0.3^{\mathrm{c}}$ & $<0.01$ & 0.02 \\
\hline Milk yield, L/d & $24.6^{\mathrm{a}}$ & $20.1^{\mathrm{b}}$ & $16.1^{\mathrm{c}}$ & $<0.01$ & 1.33 \\
\hline Fat, $\%$ & $3.8^{\mathrm{ab}}$ & $4.0^{\mathrm{a}}$ & $3.5^{\mathrm{b}}$ & 0.04 & 0.15 \\
\hline Protein, \% & $3.4^{\mathrm{a}}$ & $3.2^{\mathrm{a}}$ & $2.8^{\mathrm{b}}$ & $<0.01$ & 0.17 \\
\hline Lactose, $\%$ & 4.6 & 4.5 & 4.2 & NS & 0.15 \\
\hline Fat yield, $\mathrm{kg} / \mathrm{d}$ & $0.93^{\mathrm{a}}$ & $0.79^{\mathrm{b}}$ & $0.58^{\mathrm{c}}$ & $<0.01$ & 0.05 \\
\hline Protein yield, $\mathrm{kg} / \mathrm{d}$ & $0.82^{\mathrm{a}}$ & $0.64^{\mathrm{b}}$ & $0.47^{\mathrm{c}}$ & $<0.01$ & 0.04 \\
\hline Lactose yield, $\mathrm{kg} / \mathrm{d}$ & $1.13^{\mathrm{a}}$ & $0.90^{\mathrm{b}}$ & $0.70^{\mathrm{c}}$ & $<0.01$ & 0.06 \\
\hline Rumenic acid yield, g/d & $19.0^{\mathrm{a}}$ & $10.8^{\mathrm{b}}$ & $2.8^{\mathrm{c}}$ & $<0.01$ & 1.13 \\
\hline
\end{tabular}

${ }^{\mathrm{a}-\mathrm{c}}$ Values in the same row not sharing a common superscript are significantly different $(P<0.05)$.

${ }^{1}$ Diets were grazing $(\mathrm{G})$, zero-grazing $(\mathrm{ZG})$, and grass silage (GS) plus $3 \mathrm{~kg}$ of concentrate to all diets. 
Table 3. Fatty acid composition of the experimental diets and concentrate supplement

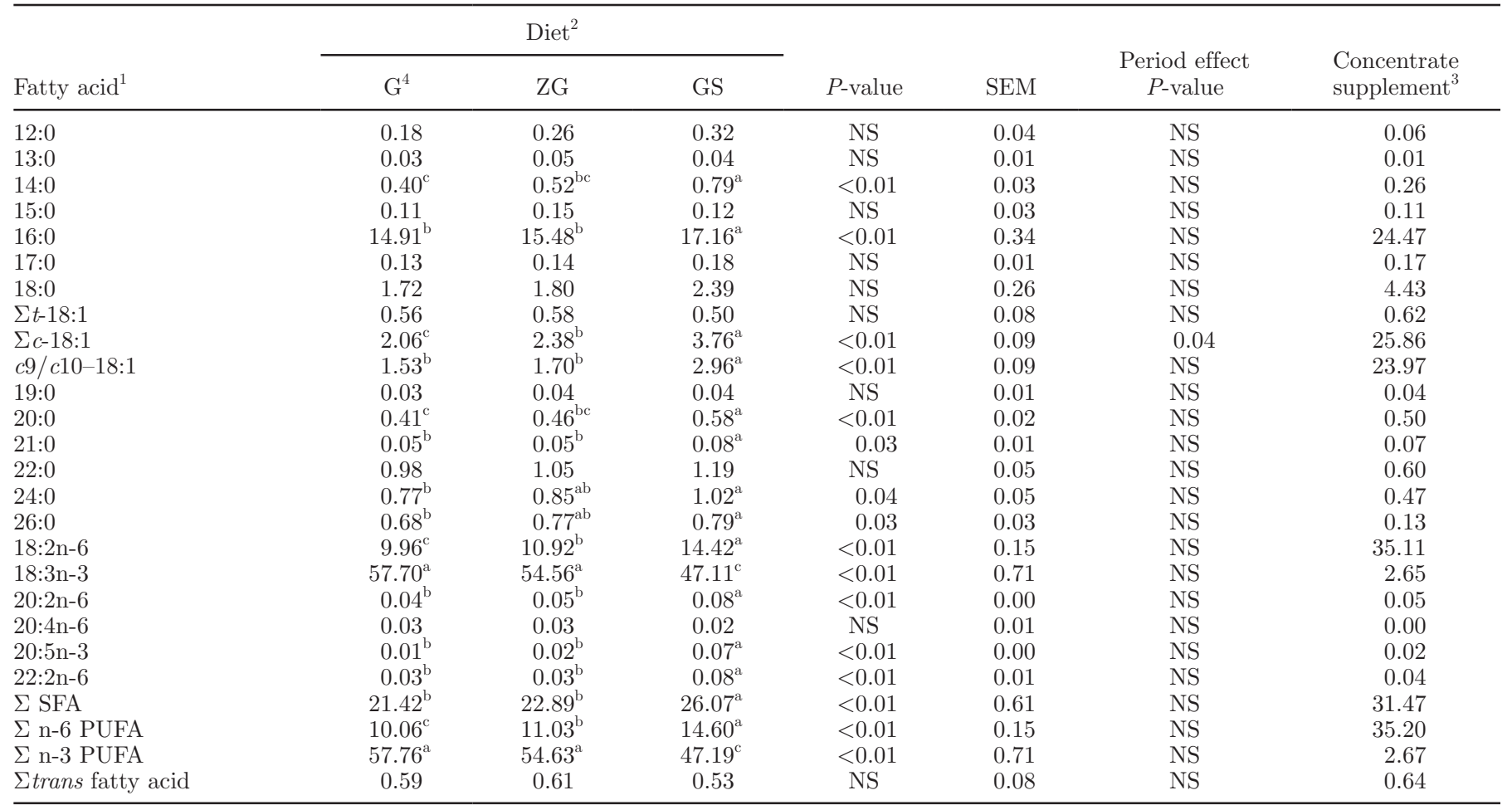

${ }^{\mathrm{a}-\mathrm{c}}$ Values within rows with different superscript are significantly different $(P<0.05)$.

${ }^{1}$ Fatty acids are expressed as a percentage of total fatty acid methyl esters; $c=c i s ; t=$ trans; SFA $=$ saturated fatty acid (12:0 to 26:0); PUFA $=$ polyunsaturated fatty acid.

${ }^{2} \mathrm{G}=$ grazing; $\mathrm{ZG}=$ zero-grazing; $\mathrm{GS}=$ grass silage.

${ }^{3}$ Concentrate supplement containing rolled barley, 30\%; citrus pulp, $46 \%$; soybean meal, 18\%; soybean oil, $3 \%$; and mineral/vitamin mix, $3 \%$ was offered to all cows at $3 \mathrm{~kg} / \mathrm{d}$.

${ }^{4} \mathrm{G}=$ fatty acid composition for $\mathrm{G}$ cows estimated from herbage snips or consumed grass. The concentrations of 16:0, $c 9 / c 10-18: 1,18: 2 \mathrm{n}-6$, and 18:3n-3 was 16.97, 1.88, 10.96, and 51.39, respectively, in G diet when estimated from grass cuts or offered grass.

reported in studies by Runcie (1960) and Paetzold and Stottmeister (1966).

The lower milk fat percentage for GS compared with $\mathrm{G}$ and ZG could be caused by diet-induced differences in rumen fermentation pattern evidenced by the differences in the odd and branched chain fatty acids (OBCFA) in milk (discussed under milk FA composition). Milk protein percentage was lower for GS, with no difference between G and ZG. Lower milk protein percentage has been reported previously for silage compared with grass-based diets (Keady et al., 1995; Younge et al., 2004) and this may be because of the lower flow of microbial nitrogen and total amino acid nitrogen for silage compared with grass-based diets (Younge et al., 2004). Milk lactose percentage was not different among the treatments.

\section{Forage FA Composition}

The FA composition of grazed grass was determined from offered grass (GC) as well as consumed grass (HS).
The FA composition of the consumed grass along with ZG and GS is tabulated in Table 3, and the important FA in the offered grass is reported as a footnote. The relevance of HS as equivalent to the consumed grass is discussed in the "Substrate Intake" section below. Linolenic acid (18:3n-3) represented the major FA in the forage, accounting for $47 \%$ in grass silage and about $56 \%$ in fresh grass (Table 3). The concentrations of n-6 PUFA were greater for grass silage compared with grazed grass and zero-grazed grass, whereas the total n-3 PUFA content was greater for grazed grass and zero-grazed grass than for grass silage. There was no period effect on the composition of FA except for total cis(c)-18:1, indicating that the grass was almost similar across the periods.

\section{Substrate Intake}

It is well established that cows tend to graze selectively and the degree of selection is influenced by the amount of forage available (Hardison et al., 1954; Lesperance et 
Table 4. Substrate intake (from total DMI)

\begin{tabular}{|c|c|c|c|c|c|c|}
\hline \multirow{2}{*}{ Variable } & \multicolumn{4}{|c|}{$\operatorname{Diet}^{1}$} & \multirow{2}{*}{$P$-value } & \multirow{2}{*}{ SEM } \\
\hline & \multicolumn{2}{|c|}{$\mathrm{G}^{2}$} & $\mathrm{ZG}$ & GS & & \\
\hline $\begin{array}{l}\text { Linoleic acid }(18: 2 \mathrm{n}-6) \text { intake, } \mathrm{g} / \mathrm{d} \\
\text { Linolenic acid }(18: 3 \mathrm{n}-3) \text { intake, } \mathrm{g} / \mathrm{d} \\
\text { Total substrate intake, }{ }^{3} \mathrm{~g} / \mathrm{d}\end{array}$ & $\begin{array}{r}91.80^{\mathrm{a}} \\
341.49^{\mathrm{a}} \\
433.28^{\mathrm{a}}\end{array}$ & $\begin{array}{r}75.46^{\mathrm{b}} \\
235.16^{\mathrm{b}} \\
310.61^{\mathrm{b}}\end{array}$ & $\begin{array}{r}76.71^{\mathrm{b}} \\
249.91^{\mathrm{b}} \\
326.62^{\mathrm{b}}\end{array}$ & $\begin{array}{r}50.54^{\mathrm{c}} \\
113.32^{\mathrm{c}} \\
163.86^{\mathrm{c}}\end{array}$ & $\begin{array}{l}<0.01 \\
<0.01 \\
<0.01\end{array}$ & $\begin{array}{r}2.90 \\
17.24 \\
17.89\end{array}$ \\
\hline
\end{tabular}

al., 1960). Because cows on diet $\mathrm{G}$ were offered $20 \mathrm{~kg} / \mathrm{d}$ of DM (the higher range of the daily herbage allowance normally offered to cows at this stage of lactation), a high probability of selective grazing would be expected with these cows.

Collection of HS as representative of the grass actually consumed by grazing cows has been used in several studies (Kennedy et al., 2005, 2006; McEvoy et al., 2008). Furthermore, the composition of the whole herbage offered (grass cuts) to grazing cows has been reported as an unreliable estimate of what cows actually consume when there is an opportunity for selective grazing (Johnston-Wallace, 1937; Johnston-Wallace and Kennedy, 1944; Hardison et al., 1954; Fontenot and Blaser, 1965). Thus, basing substrate intake on the composition of grass cuts (GC or offered herbage) would not reflect what the cows were actually consuming. Therefore, LA and LNA intakes calculated from the HS (consumed grass) were taken as being representative of the substrate consumed from grass by the cows on diet G. Intakes of LA and LNA estimated from offered grass (GC) were also tabulated for a discussion of the differences between offered and consumed grass for $\mathrm{G}$ cows (Table 4). It was assumed that there was no difference in the concentrations of LA and LNA be- tween what was offered and consumed by the cows on ZG and GS because the form in which these diets were fed prevented the animals from being selective.

There were no significant differences in LA and LNA intake per day between $\mathrm{G}$ and $\mathrm{ZG}$ when the respective values for $G$ estimated from offered grass were compared with ZG (Table 4). However, the intakes of LA and LNA were greater for G compared with ZG when the respective values for $G$ were quantified from consumed grass (HS). Lesser intakes of LA and LNA for GS compared with other treatments could be explained by the lower DMI as well as the lower proportion of LNA in grass silage. Lower proportions of LNA for grass silage relative to grazed grass and zero-grazed grass could be caused by oxidation of PUFA during wilting and ensiling. Losses of FA during forage conservation and storage is well documented (Lough and Anderson, 1973; Steele and Noble, 1983) and is mediated by plant lipases releasing LNA and LA from the cut surface of the plant tissue (Thomas, 1986).

\section{Rumen Factors}

In the previous section, we observed that there were differences in LA and LNA intakes as well as total

Table 5. Rumen $\mathrm{pH}$, volatile fatty acids, and ammonia nitrogen $\left(\mathrm{NH}_{3}-\mathrm{N}\right)$

\begin{tabular}{|c|c|c|c|c|c|}
\hline \multirow[b]{2}{*}{ Rumen factor } & \multicolumn{3}{|c|}{ Diet $^{1}$} & \multirow[b]{2}{*}{$P$-value } & \multirow[b]{2}{*}{ SEM } \\
\hline & $\mathrm{G}$ & $\mathrm{ZG}$ & GS & & \\
\hline Rumen pH & $6.32^{\mathrm{b}}$ & $6.79^{\mathrm{a}}$ & $6.71^{\mathrm{a}}$ & $<0.01$ & 0.08 \\
\hline Total VFA, $\mu \mathrm{mol} / \mathrm{mL}$ & 85.91 & 86.80 & 78.61 & NS & 5.94 \\
\hline Acetate, $\mu \mathrm{mol} / \mathrm{mL}$ & 49.49 & 53.27 & 47.27 & NS & 3.18 \\
\hline Propionate, $\mu \mathrm{mol} / \mathrm{mL}$ & 16.63 & 15.29 & 14.61 & NS & 1.02 \\
\hline Butyrate, $\mu \mathrm{mol} / \mathrm{mL}$ & 11.51 & 10.63 & 10.61 & NS & 0.79 \\
\hline Acetate: propionate & $2.98^{\mathrm{bc}}$ & $3.48^{\mathrm{a}}$ & $3.23^{\mathrm{b}}$ & $<0.01$ & 0.10 \\
\hline $\mathrm{NH}_{3}-\mathrm{N}, \mu \mathrm{g} / \mathrm{mL}$ & 24.88 & 25.65 & 16.06 & NS & 5.92 \\
\hline Wet rumen fill, kg & $88.75^{\mathrm{b}}$ & $102.50^{\mathrm{a}}$ & $103.30^{\mathrm{a}}$ & $<0.01$ & 9.32 \\
\hline Dry rumen fill, kg & 9.65 & 10.73 & 10.09 & NS & 1.08 \\
\hline
\end{tabular}

${ }^{\mathrm{a}-\mathrm{c}}$ Values in the same row not sharing a common superscript are significantly different $(P<0.05)$.

${ }^{1} \mathrm{G}=$ grazing; $\mathrm{ZG}=$ zero-grazing; $\mathrm{GS}=$ grass silage plus $3 \mathrm{~kg}$ of concentrate to all the diets. 
Table 6. Effect of treatments on rumen fatty acid composition

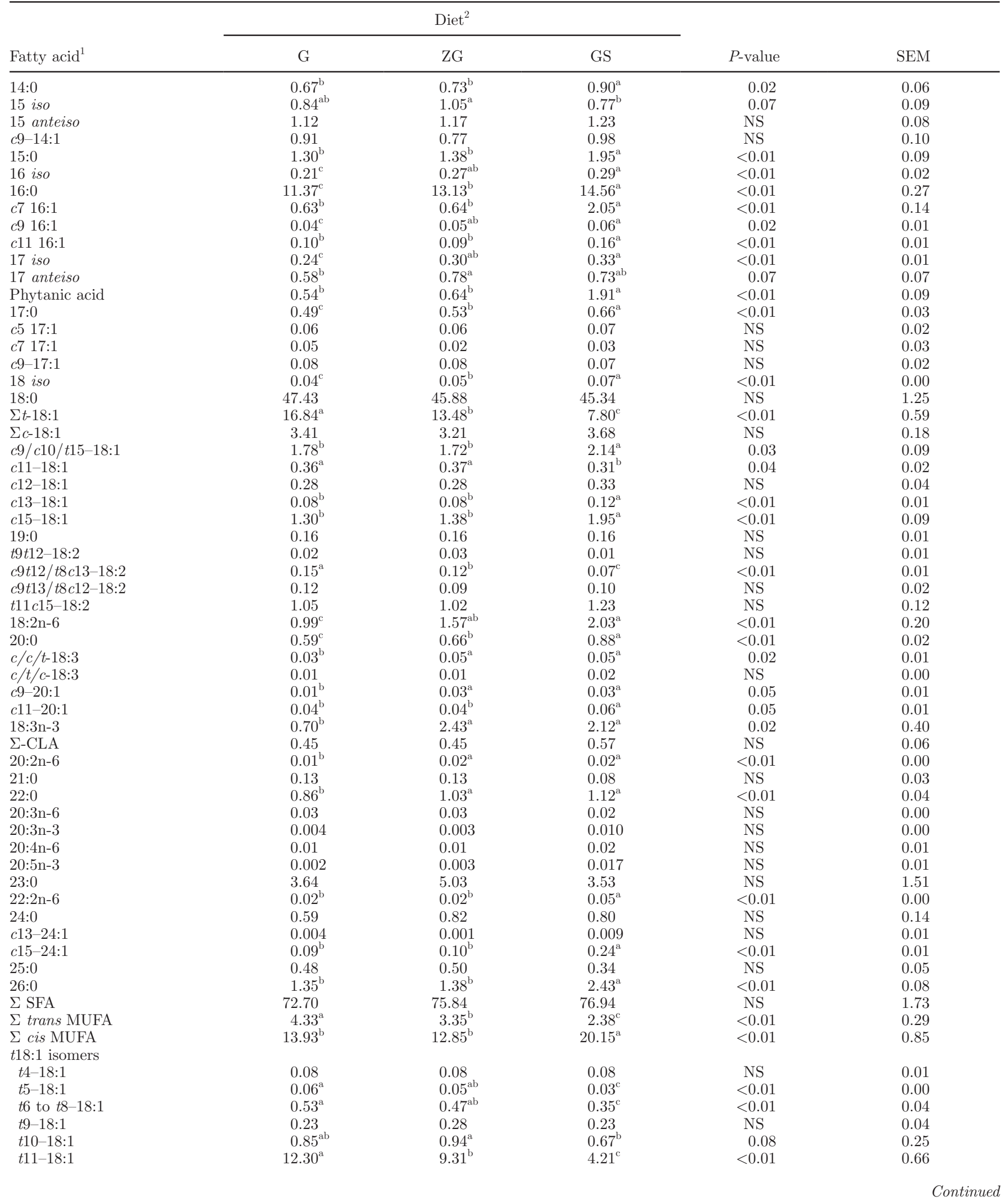


Table 6 (Continued). Effect of treatments on rumen fatty acid composition

\begin{tabular}{|c|c|c|c|c|c|}
\hline Fatty acid ${ }^{1}$ & \multicolumn{3}{|c|}{$\operatorname{Diet}^{2}$} & $P$-value & SEM \\
\hline$t 10: t 11-18: 1$ & $0.08^{\mathrm{b}}$ & $0.11^{\mathrm{b}}$ & $0.17^{\mathrm{a}}$ & $<0.01$ & 0.02 \\
\hline$t 13 / 14 / c 6-c 8-18: 1$ & 2.10 & 1.71 & 1.65 & NS & 0.28 \\
\hline \multicolumn{6}{|l|}{ CLA isomers $^{3}$} \\
\hline$c 9 t 11-\mathrm{CLA}$ & $0.09^{\mathrm{b}}$ & $0.09^{\mathrm{b}}$ & $0.13^{\mathrm{a}}$ & 0.04 & 0.03 \\
\hline$t 11 t 13-\mathrm{CLA}$ & 0.17 & 0.18 & 0.13 & NS & 0.02 \\
\hline$t 12 t 14$-CLA & 0.06 & 0.06 & 0.08 & NS & 0.02 \\
\hline
\end{tabular}

${ }^{\mathrm{a}-\mathrm{c}}$ Values in the same row not sharing a common superscript are significantly different $(P<0.05)$.

${ }^{1} c=$ cis $;=$ trans; CLA = conjugated linoleic acid; SFA = saturated fatty acid (14:0 to 26:0 including branched-chain fatty acids); MUFA = monounsaturated fatty acid; fatty acids are expressed as a percentage of total fatty acid methyl esters.

${ }^{2} \mathrm{G}=$ grazing; $\mathrm{ZG}=$ zero-grazing; $\mathrm{GS}=$ grass silage; plus $3 \mathrm{~kg}$ of concentrate to all diets.

${ }^{3} \mathrm{CLA}$ isomers were only resolved using GLC, not additional $\mathrm{Ag}^{+}$-HPLC.

substrate intake among the treatments. Apart from treatments being different in the amount of substrate they supplied, diets could also influence the rumen environment differently and in turn modify the microbial activity associated with biohydrogenation of PUFA in the rumen. Some of the factors reported to influence rumen biohydrogenation of PUFA based on in vitro and in vivo studies include rumen $\mathrm{pH}$ (Van Nevel and Demeyer, 1996; Martin and Jenkins, 2002), rumen fill/ passage rate (Qiu et al., 2004), amount and source of lipid (Bell et al., 2006; Cruz-Hernandez et al., 2007), possible interactions between forage and lipid source (Chilliard and Ferlay, 2004), and inhibition of rumen biohydrogenation by components in specific botanical species of the forage (Leiber et al., 2005). Discussion here will be confined to the differences in rumen $\mathrm{pH}$, fermentation end products, rumen fill and its possible influence on lipolysis and biohydrogenation of PUFA in the rumen. The rumen variables measured are presented in Table 5 .

Rumen $\boldsymbol{p H}$. Rumen $\mathrm{pH}$ was lower for $\mathrm{G}$ with no significant difference between ZG and GS. Rumen $\mathrm{pH}$ is determined by various factors, but mainly by structural properties of the feed. This in turn influenced the chewing activity and flow of saliva to the rumen. Lower $\mathrm{pH}$ for $\mathrm{G}$ compared with GS could be explained by the lower NDF values recorded in grazed grass. Higher fiber content promotes chewing and increases salivation to buffer the acids produced in the rumen. In the present study the mean $\mathrm{pH}$ of silage juice was 4.1, but the rumen $\mathrm{pH}$ for GS compared with $\mathrm{G}$ was not lower, suggesting an efficient buffering system in the animals to compensate for the lower $\mathrm{pH}$ of the silage diet. The difference in rumen $\mathrm{pH}$ between $\mathrm{G}$ and $\mathrm{ZG}$ could be due to difference in digestibility of the grass. Theoretically the offered grass for grazing and zero-grazing animals was the same, but there was greater opportunity for grazing animals to choose the more digestible leafy portions and reduce the intake of more fibrous stem portions of the grass. Consistent with this, higher NDF values were recorded for zero-grazed grass compared with grazed grass (45.4 vs. $41.5 \%$ DM). Fresh grass is generally higher in soluble carbohydrates compared with grass silage. Although not analyzed, differences in water-soluble carbohydrates (besides fiber) could have also contributed to the differences in rumen $\mathrm{pH}$ between $\mathrm{G}$ and GS.

VFA and Ammonia Nitrogen in the Rumen. There was no significant difference in the mean VFA (total as well as individual) and ammonia nitrogen concentrations in the rumen among the treatments. We also attempted to investigate whether there was a difference in rumen fermentation pattern among the treatments using milk OBCFA and milk fat percentage as alternatives. There is growing evidence to support the use of milk OBCFA to predict differences in rumen fermentation pattern (Vlaeminck et al., 2006b) and, in general, as a diagnostic tool for rumen function in relation to dietary effects (Valeminck et al., 2006a). The sum of iso FA (13:0 iso, 14:0 iso, 15:0 iso, 16:0 iso, and 17:0 iso) and anteiso FA (13:0 anteiso, 15:0 anteiso, and 17:0 anteiso) in milk were significantly greater for G and ZG than for GS, with no difference between G and ZG indicating that the fermentation pattern was possibly different for GS compared with G and ZG. Milk fat percentage was significantly less for GS with comparable values for $\mathrm{G}$ and $\mathrm{ZG}$. Because a shift in rumen fermentation pattern is determined by the relative proportions of cellulolytic and amylolytic bacteria in the rumen, the results from OBCFA pattern in milk 
Table 7. Effect of treatments on plasma fatty acid composition

\begin{tabular}{|c|c|c|c|c|c|}
\hline Fatty acid ${ }^{1}$ & \multicolumn{3}{|c|}{ Diet $^{2}$} & $P$-value & SEM \\
\hline 14:0 & 0.51 & 0.51 & 0.56 & NS & 0.04 \\
\hline 15 anteiso & 0.89 & 0.83 & 0.89 & NS & 0.07 \\
\hline$c 9-14: 1$ & 0.003 & 0.040 & 0.004 & NS & 0.02 \\
\hline $15: 0$ & $0.68^{\mathrm{b}}$ & $0.72^{\mathrm{b}}$ & $0.84^{\mathrm{a}}$ & 0.03 & 0.03 \\
\hline$\Sigma c-16: 1$ & 1.69 & 1.62 & 1.94 & NS & 0.12 \\
\hline$t 5-16: 1$ & $0.09^{\mathrm{ab}}$ & $0.07^{\mathrm{b}}$ & $0.13^{\mathrm{a}}$ & 0.03 & 0.02 \\
\hline$t 6-8-16: 1$ & 0.15 & 0.15 & 0.18 & NS & 0.01 \\
\hline$t 9-16: 1$ & $0.32^{\mathrm{a}}$ & $0.26^{\mathrm{b}}$ & $0.15^{\mathrm{c}}$ & $<0.01$ & 0.03 \\
\hline$c 7 / t 11 \quad 16: 1$ & 0.59 & 0.65 & 0.73 & NS & 0.05 \\
\hline$c 916: 1$ & 0.91 & 0.81 & 1.02 & NS & 0.09 \\
\hline $17: 0$ & $0.80^{\mathrm{b}}$ & $0.82^{\mathrm{b}}$ & $0.99^{\mathrm{a}}$ & $<0.01$ & 0.05 \\
\hline$c 517: 1 / 18: 1 \mathrm{DMA}^{3}$ & $0.12^{\mathrm{b}}$ & $0.13^{\mathrm{b}}$ & $0.19^{\mathrm{a}}$ & $<0.01$ & 0.01 \\
\hline c7 17:1/18:1 DMA & $0.28^{\mathrm{b}}$ & $0.31^{\mathrm{b}}$ & $0.49^{\mathrm{a}}$ & $<0.01$ & 0.02 \\
\hline$c 9-17: 1$ & $0.40^{\mathrm{b}}$ & $0.35^{\mathrm{b}}$ & $0.57^{\mathrm{a}}$ & $<0.01$ & 0.02 \\
\hline$c 11-17: 1$ & 0.03 & 0.03 & 0.03 & NS & 0.01 \\
\hline 18 iso & $0.06^{\mathrm{ab}}$ & $0.06^{\mathrm{b}}$ & $0.07^{\mathrm{a}}$ & 0.05 & 0.00 \\
\hline $18: 0$ & 14.25 & 13.80 & 13.92 & NS & 0.91 \\
\hline$\Sigma t-18: 1$ & $3.79^{\mathrm{a}}$ & $2.79^{\mathrm{b}}$ & $1.84^{\mathrm{c}}$ & $<0.01$ & 0.27 \\
\hline$\Sigma c-18: 1$ & $9.97^{\mathrm{b}}$ & $8.63^{\mathrm{b}}$ & $12.42^{\mathrm{a}}$ & $<0.01$ & 0.51 \\
\hline$c 6-c 8-18: 1$ & $0.27^{\mathrm{b}}$ & $0.29^{\mathrm{b}}$ & $0.46^{\mathrm{a}}$ & 0.01 & 0.04 \\
\hline$c 9 / c 10-18: 1$ & $8.73^{\mathrm{b}}$ & $7.46^{\mathrm{b}}$ & $10.99^{\mathrm{a}}$ & $<0.01$ & 0.48 \\
\hline$c 11-18: 1$ & 0.36 & 0.34 & 0.32 & NS & 0.03 \\
\hline$c 12-18: 1$ & $0.42^{\mathrm{b}}$ & $0.37^{\mathrm{b}}$ & $0.49^{\mathrm{a}}$ & 0.01 & 0.05 \\
\hline$c 13-18: 1$ & 0.08 & 0.06 & 0.06 & NS & 0.01 \\
\hline $18: 2 n-6$ & 26.38 & 26.41 & 25.31 & NS & 0.92 \\
\hline 20:0 & $0.09^{\mathrm{b}}$ & $0.11^{\mathrm{b}}$ & $0.13^{\mathrm{a}}$ & $<0.01$ & 0.00 \\
\hline $18: 3 n-6$ & $0.71^{\mathrm{b}}$ & $0.77^{\mathrm{ab}}$ & $0.89^{\mathrm{a}}$ & 0.08 & 0.12 \\
\hline$c / c / t-18: 3$ & $0.17^{\mathrm{a}}$ & $0.19^{\mathrm{a}}$ & $0.09^{\mathrm{b}}$ & $<0.01$ & 0.01 \\
\hline$c / t / t-18: 3$ & $0.12^{\mathrm{a}}$ & $0.09^{\mathrm{b}}$ & $0.12^{\mathrm{a}}$ & $<0.01$ & 0.01 \\
\hline$c 7-20: 1 / t, c, c-18: 3$ & $0.20^{\mathrm{a}}$ & $0.17^{\mathrm{b}}$ & $0.09^{c}$ & $<0.01$ & 0.01 \\
\hline$c 9-20: 1$ & 0.02 & 0.03 & 0.03 & NS & 0.00 \\
\hline$c 10-20: 1$ & $0.07^{\mathrm{ab}}$ & $0.07^{\mathrm{b}}$ & $0.08^{\mathrm{a}}$ & 0.09 & 0.00 \\
\hline$c 11-20: 1$ & 0.03 & 0.02 & 0.04 & NS & 0.01 \\
\hline $18: 3 n-3$ & $12.01^{\mathrm{a}}$ & $14.00^{\mathrm{a}}$ & $7.32^{\mathrm{b}}$ & $<0.01$ & 0.85 \\
\hline $18: 4 n-3$ & $0.44^{\mathrm{a}}$ & $0.46^{\mathrm{a}}$ & $0.30^{\mathrm{b}}$ & 0.05 & 0.10 \\
\hline$\Sigma$-CLA & $0.38^{\mathrm{a}}$ & $0.33^{\mathrm{ab}}$ & $0.27^{\mathrm{b}}$ & 0.01 & 0.02 \\
\hline $20: 2 n-6$ & 0.07 & 0.08 & 0.08 & NS & 0.00 \\
\hline 21:0 & 0.01 & 0.01 & 0.02 & NS & 0.01 \\
\hline $22: 0$ & 0.08 & 0.06 & 0.13 & NS & 0.03 \\
\hline $20: 3 n-6$ & 1.07 & 1.06 & 1.19 & NS & 0.15 \\
\hline $20: 3 n-3$ & $0.01^{\mathrm{b}}$ & $0.02^{\mathrm{a}}$ & $0.01^{\mathrm{ab}}$ & 0.05 & 0.00 \\
\hline $20: 4 n-6$ & 0.97 & 1.10 & 1.33 & NS & 0.20 \\
\hline $20: 4 n-3$ & $0.85^{\mathrm{a}}$ & $0.91^{\mathrm{a}}$ & $0.59^{\mathrm{b}}$ & 0.03 & 0.12 \\
\hline 23:0 & 0.47 & 0.50 & 0.49 & NS & 0.03 \\
\hline $20: 5 n-3$ & 1.15 & 1.17 & 1.23 & NS & 0.37 \\
\hline
\end{tabular}


Table 7 (Continued). Effect of treatments on plasma fatty acid composition

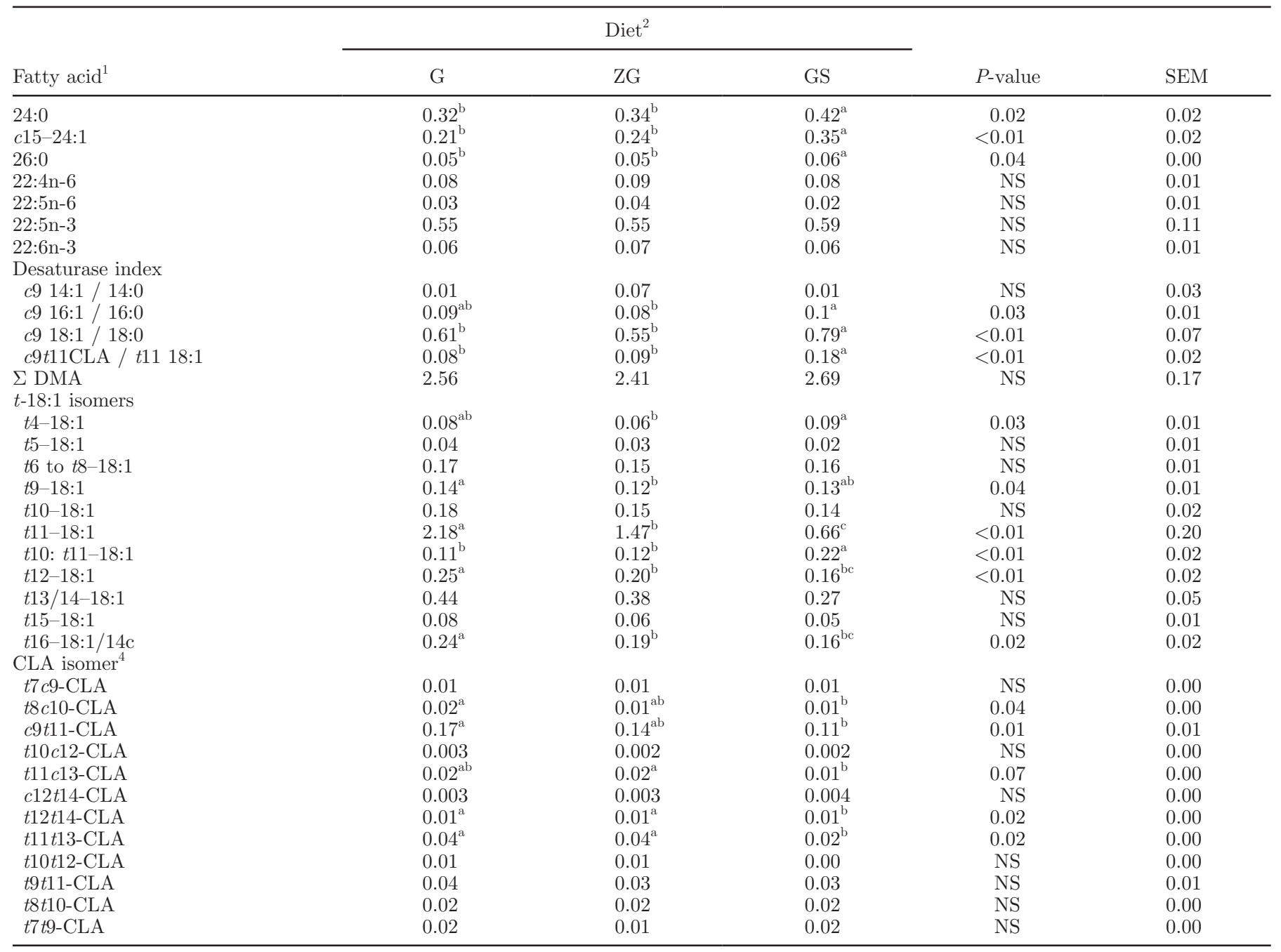

${ }^{\mathrm{a}-\mathrm{c}}$ Values in the same row not sharing a common superscript are significantly different $(P<0.05)$.

${ }^{1} c=c i s ; t=$ trans; CLA = conjugated linoleic acid; fatty acids are expressed as a percentage of total fatty acid methyl esters.

${ }^{2} \mathrm{G}=$ grazing; $\mathrm{ZG}=$ zero-grazing; $\mathrm{GS}=$ grass silage; plus $3 \mathrm{~kg}$ of concentrate to all diets.

${ }^{3}$ Dimethyl acetal.

${ }^{4}$ CLA isomers were resolved using GLC and $\mathrm{Ag}^{+}$-HPLC.

reflect a possible shift in rumen bacterial population between the treatments (particularly GS from $G$ and $\mathrm{ZG}$ ), but the difference may not have been large enough to produce a significant difference in indicators of rumen fermentation pattern (VFA and ammonia nitrogen) or this was not detected because of infrequent sampling.

Rumen Fill and Passage Rate. Rumen fill and passage rate can influence milk RA content because these factors can influence the degree of biohydrogenation of unsaturated FA. Chaves and Boudon (2005), in a study designed to test the influence of rumen fill on intake and milk production in dairy cows fed perennial ryegrass, reported a negative relationship between rumen fill and DMI. Based on this, it was anticipated that less rumen fill would be associated with increased DMI, which in turn would increase digesta passage rate resulting in greater accumulation of biohydrogenation intermediates for $\mathrm{G}$ than for GS. Consistent with this, rumen fill (wet) was less for G compared with GS (Table 5 ), and total DMI was greater for G than for GS (Table 2 ). However, dry rumen fill was not different across the treatments. Regression analysis of rumen fill (both wet and dry) and DMI (forage DMI and total DMI) was not significant (data not presented) suggesting that the difference in rumen fill and total DMI in the current study were not correlated. 


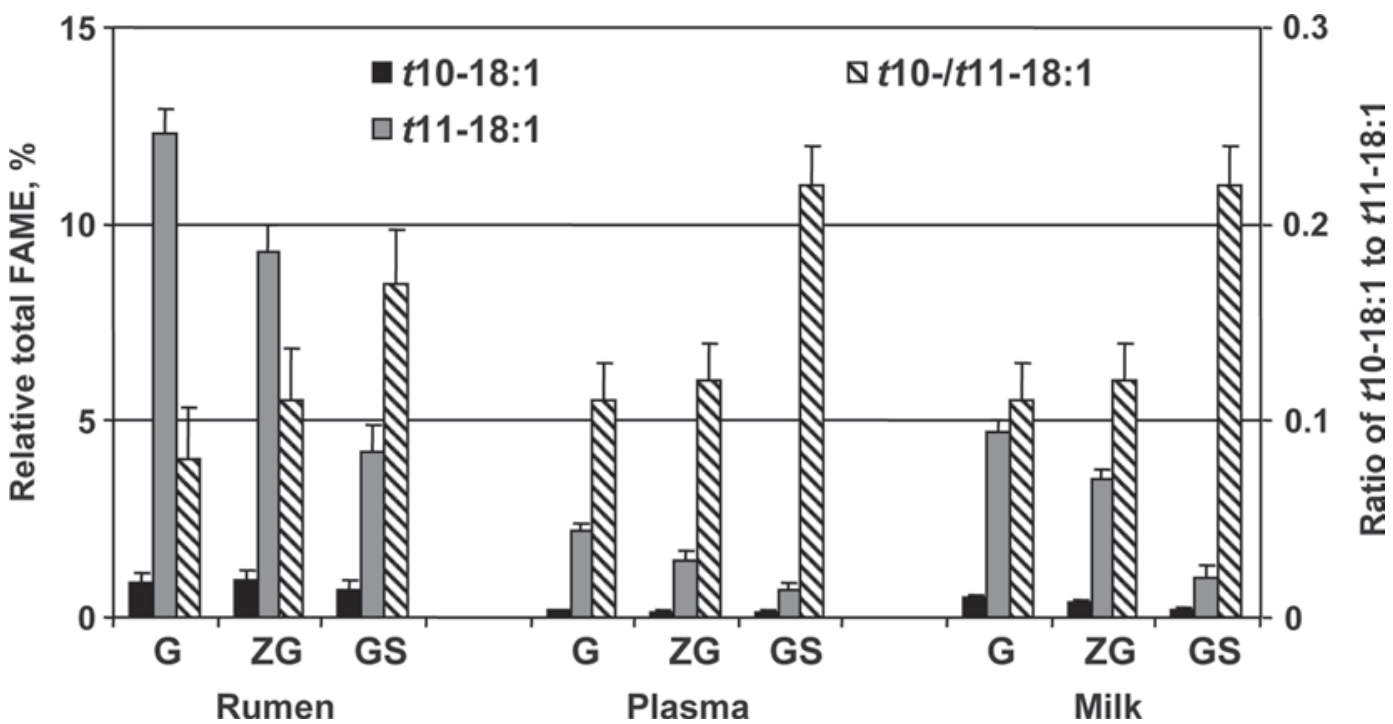

Figure 1. Ratio of trans(t)10:trans11-18:1 in rumen, plasma, and milk of cows allowed to graze (G), zero-grazed (ZG), or fed grass silage (GS). The isomers $t 10$ - and $t 11-18: 1$ are expressed as relative percentage of total fatty acid methyl esters (FAME) on the left y-axis; the ratio of t10-18:1 to $t 11-18: 1$ is shown on the right y-axis.

\section{Rumen and Plasma FA Composition}

The FA composition of the rumen contents for the different treatments is shown in Table 6. The FA composition of the rumen reflects feed lipids as well as metabolic products of dietary PUFA by the rumen microbes. The most abundant ruminal FA was 18:0 (ranging from 45 to $47 \%$ ) that showed no treatment effect, followed by 16:0 (11-14\%) and trans $(\boldsymbol{t}) 11-18: 1$ (4-12\%). Ruminal concentration of 16:0 was greater for GS than for G and ZG. Vaccenic acid was the second most abundant FA for $\mathrm{G}$ and the third most abundant FA for ZG and GS diets. Total CLA isomers in rumen ranged from 0.45 to $0.57 \%$ and were not different among the treatments. Ruminal lipids were high in total saturated FA, which included long-chain saturated FA up to 26:0. Phytanic acid, the isoprenoid saturated FA derived from the phytol side chain of chlorophyll, was present at greater concentrations for GS with no difference between $\mathrm{G}$ and $\mathrm{ZG}$.

Ruminal concentrations of LA (18:2n-6) and LNA (18:2n-3) were greater for GS than for G, but this did not translate into correspondingly greater levels of VA for the GS group, suggesting that there were differences in lipolysis, degree of PUFA biohydrogenation, and possibly rumen bacterial populations across the treatments. It is well established that ingested lipids are mainly hydrolyzed by rumen bacterial lipases and to a lesser extent by plant lipases; see review by Jenkins et al. (2008). Faruque et al. (1974) reported that plant lipases in the leaves of pasture plants remain active for at least $5 \mathrm{~h}$ in the presence of metabolizing rumen microorganisms, indicating that lipolysis of ruminal lipids for G and ZG diets could be influenced by both plant lipases and bacterial lipases, whereas for GS diets, lipolysis was influenced mainly by bacterial lipases (Boufaïed et al., 2003a,b). Thus, the reduced ruminal concentrations of LA and LNA for G and ZG could be due to a more active biohydrogenation compared with that for GS.

The plasma FA composition presented in Table 7 was obtained by combining the results of both acid- and base-methylation procedures (Kramer et al., 2008). The derivatization products obtained from methylation of $\mathrm{O}$-acyl and $\mathrm{N}$-acyl side-chains yielded FAME, whereas those from alk-1-enyl ethers yielded DMA. Total DMA ranged from 2.4 to $2.7 \%$ of the total FAME and were not different among the treatments. Plasma concentrations of the 2 most abundant FA, LA and 18:0, were not different among treatments. Plasma concentrations of LNA were lesser for GS than for G and ZG, whereas the concentration of $c 9-/ c 10-18: 1$ was greater for GS than for $\mathrm{G}$ and $\mathrm{ZG}$. Total CLA isomers in plasma ranged from 0.27 to $0.38 \%$ with lower values for GS compared with G. Phytanic acid, which coeluted with 17:0 anteiso using the $175^{\circ} \mathrm{C}$ program, could be resolved using the $150^{\circ} \mathrm{C}$ program. Plasma phytanic acid concentrations showed the same treatment differences as were found in the ruminal lipids; they were significantly higher for GS with no difference between $\mathrm{G}$ and ZG.

VA and 110-18:1 in Rumen and Plasma. There were significant differences in ruminal total $t-18: 1$ and VA (Table 6) among the treatments, with greater values recorded for $\mathrm{G}$ than for ZG and GS. This could be 
Table 8. Effect of treatments on milk fatty acid composition

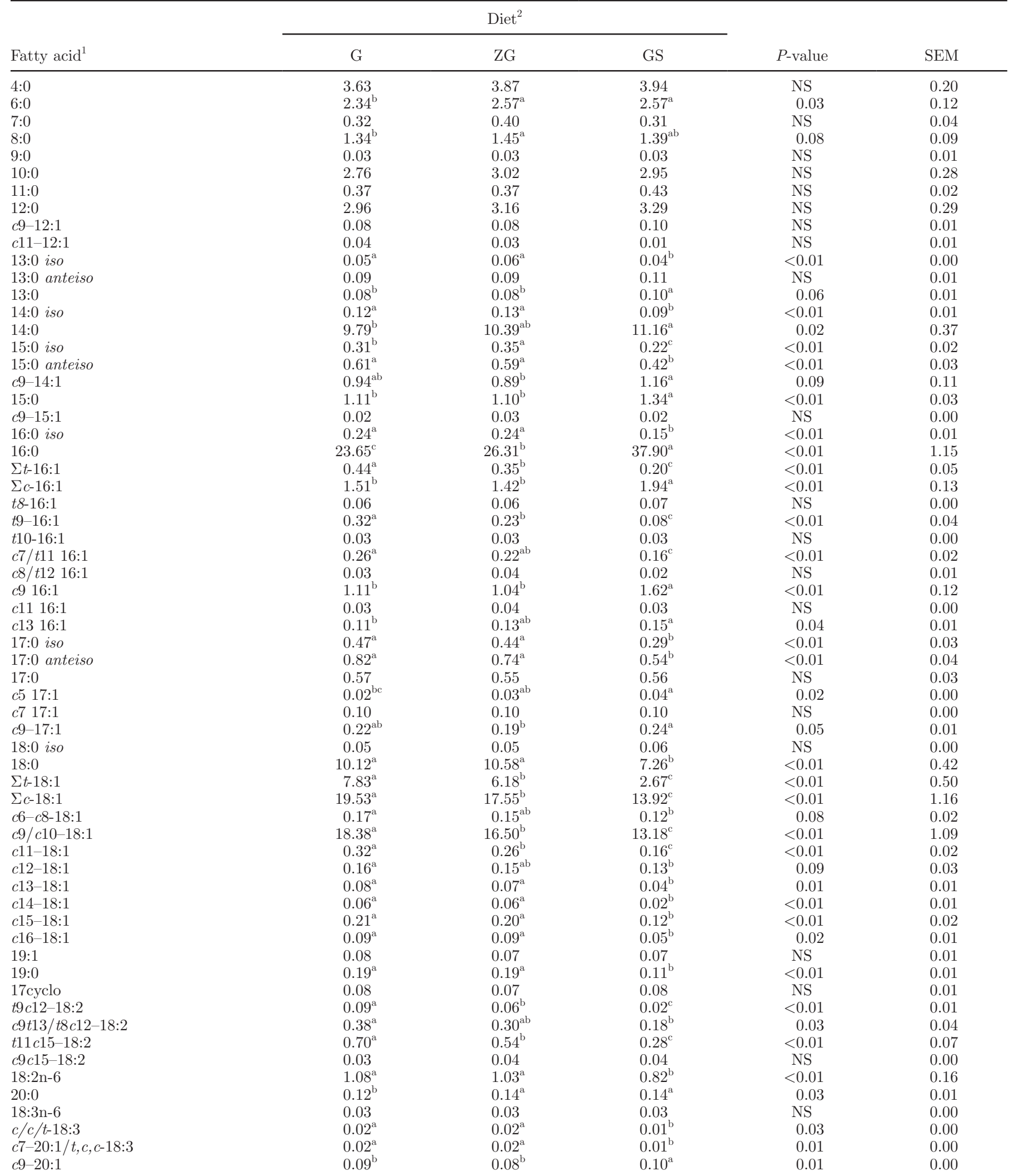


Table 8 (Continued). Effect of treatments on milk fatty acid composition

\begin{tabular}{|c|c|c|c|c|c|}
\hline Fatty $\operatorname{acid}^{1}$ & \multicolumn{3}{|c|}{ Diet $^{2}$} & $P$-value & SEM \\
\hline$c 11-20: 1$ & 0.03 & 0.02 & 0.03 & NS & 0.00 \\
\hline$\Sigma-\mathrm{CLA}$ & $2.39^{\mathrm{a}}$ & $1.66^{\mathrm{b}}$ & $0.69^{c}$ & $<0.01$ & 0.19 \\
\hline $20: 2 n-6$ & 0.02 & 0.02 & 0.02 & NS & 0.00 \\
\hline $22: 0$ & 0.08 & 0.08 & 0.07 & NS & 0.01 \\
\hline $23: 0$ & $0.02^{\mathrm{b}}$ & $0.03^{\mathrm{a}}$ & $0.02^{\mathrm{b}}$ & 0.05 & 0.00 \\
\hline $20: 5 n-3$ & $0.05^{\mathrm{b}}$ & $0.07^{\mathrm{a}}$ & $0.05^{\mathrm{b}}$ & $<0.01$ & 0.01 \\
\hline $24: 0$ & 0.04 & 0.04 & 0.04 & NS & 0.00 \\
\hline $26: 0$ & $0.03^{\mathrm{b}}$ & $0.03^{\mathrm{b}}$ & $0.04^{\mathrm{a}}$ & 0.08 & 0.00 \\
\hline $22: 4 n-6$ & 0.01 & 0.01 & 0.01 & NS & 0.00 \\
\hline $22: 5 n-6$ & 0.02 & 0.02 & 0.01 & NS & 0.00 \\
\hline$\Sigma$ iso + anteiso $\mathrm{FA}$ & $2.76^{\mathrm{a}}$ & $2.70^{\mathrm{a}}$ & $1.91^{\mathrm{b}}$ & $<0.01$ & 0.12 \\
\hline$\Sigma$ trans $\mathrm{MUFA}$ & $8.27^{\mathrm{a}}$ & $6.53^{\mathrm{b}}$ & $2.87^{\mathrm{c}}$ & $<0.01$ & 0.53 \\
\hline$\Sigma$ cis $\mathrm{MUFA}$ & $22.60^{\mathrm{a}}$ & $20.46^{\mathrm{b}}$ & $17.66^{\mathrm{c}}$ & $<0.01$ & 1.06 \\
\hline$\Sigma$ n-6 PUFA & $1.25^{\mathrm{a}}$ & $1.22^{\mathrm{a}}$ & $1.01^{\mathrm{b}}$ & 0.01 & 0.17 \\
\hline$\Sigma \mathrm{n}-3$ PUFA & $0.91^{\mathrm{b}}$ & $1.07^{\mathrm{a}}$ & $0.53^{\mathrm{c}}$ & $<0.01$ & 0.14 \\
\hline \multicolumn{6}{|l|}{ Desaturase index } \\
\hline$c 9-14: 1 / 14: 0$ & 0.10 & 0.09 & 0.10 & NS & 0.01 \\
\hline$c 9-16: 1 / 16: 0$ & $0.05^{\mathrm{a}}$ & $0.03^{\mathrm{b}}$ & $0.04^{\mathrm{ab}}$ & 0.08 & 0.00 \\
\hline$c 9-18: 1 / 18: 0$ & $1.84^{\mathrm{a}}$ & $1.56^{\mathrm{b}}$ & $1.80^{\mathrm{ab}}$ & 0.08 & 0.11 \\
\hline$c 9 t 11-\mathrm{CLA} / t 11-18: 1$ & $0.44^{\mathrm{b}}$ & $0.40^{\mathrm{b}}$ & $0.52^{\mathrm{a}}$ & 0.02 & 0.04 \\
\hline
\end{tabular}

${ }^{\mathrm{a}-\mathrm{C}}$ Values in the same row not sharing a common superscript are significantly different $(P<0.05)$.

${ }^{1} c=c i s ; t=$ trans; CLA = conjugated linoleic acid; SFA = saturated fatty acid (4:0 to 26:0 including branched-chain fatty acids); SCFA = shorter chain fatty acid; MUFA = monounsaturated fatty acid; PUFA = polyunsaturated fatty acid; fatty acids were expressed as a percentage of total fatty acid methyl esters.

${ }^{2} \mathrm{G}=$ grazing; $\mathrm{ZG}=$ zero-grazing; $\mathrm{GS}=$ grass silage; plus $3 \mathrm{~kg}$ of concentrate to all the diets.

attributed to the differences in LA and LNA intake, degree of biohydrogenation, rumen $\mathrm{pH}$, or digesta kinetics across the treatments. In the current study, there were diet-induced differences in rumen $\mathrm{pH}$, which could have inhibited biohydrogenation of PUFA resulting in the differences in VA among the treatments. Consistent with this, Kalscheur et al. (1997) demonstrated the effect of low rumen $\mathrm{pH}$ on biohydrogenation inhibition and increased outflow of $t-18: 1$ intermediates from the rumen. More recently, FA oxidation products, which are released from fresh pastures when pasture is damaged through mastication or mechanical cutting, have also been reported to influence microbial metabolism of PUFA in the rumen because of their antimicrobial properties (Lee et al., 2007). The relative concentration of $t 10-18: 1$ in all treatments, although less than $1 \%$, was of interest because it has been suggested as an indicator of a shift in rumen bacterial populations (Cruz-Hernandez et al., 2006). Based on the greater t10- to $t 11-18: 1$ ratio, there appears to be a shift in rumen bacterial profile for GS compared with $G$ and ZG (Figure 1).
The concentrations of total $t-18: 1$ and VA in plasma (Table 7) followed a similar trend as that in rumen, but the relative amounts of these FA were 4 to 6 times lower in plasma lipids. Plasma concentrations of t10-18:1 were not different among treatments, but the t10- to $t 11-18: 1$ ratio was greater for GS than for G and ZG (Figure 1) similar to that observed in rumen. Plasma concentrations of $t 11 c 15-18: 2$, an intermediate of ruminal biohydrogenation of LNA (Griinari and Bauman, 1999), was significantly different across the treatments, with greater values for $\mathrm{G}$ than for ZG and GS indicating that there were differences in the extent of biohydrogenation of LNA in the rumen.

RA and t10c12-CLA in Rumen and Plasma. Rumenic acid in the rumen was greater for GS with no difference between G and ZG (Table 6). Because RA is an intermediate of LA biohydrogenation and is not part of the classical biohydrogenation pathway of LNA, it would be expected that the concentration of RA in the rumen would be proportional to the intake of LA in the diet (Table 4). On the contrary, the concentration of RA in the rumen was highest for GS, the diet with 
Table 9. Effect of treatments on the composition of trans-18:1 and conjugated linoleic acid (CLA) isomers in milk fat

\begin{tabular}{|c|c|c|c|c|c|}
\hline Isomer $^{1}$ & \multicolumn{3}{|c|}{$\operatorname{Diet}^{2}$} & $P$-value & SEM \\
\hline \multicolumn{6}{|c|}{ Trans 18:1 isomers } \\
\hline$t 5-18: 1$ & $0.03^{\mathrm{a}}$ & $0.03^{\mathrm{a}}$ & $0.02^{\mathrm{b}}$ & $<0.01$ & 0.00 \\
\hline t6 to $t 8-18: 1$ & $0.34^{\mathrm{a}}$ & $0.31^{\mathrm{b}}$ & $0.20^{\mathrm{c}}$ & $<0.01$ & 0.03 \\
\hline$t 9-18: 1$ & $0.30^{\mathrm{a}}$ & $0.26^{\mathrm{b}}$ & $0.17^{\mathrm{c}}$ & $<0.01$ & 0.03 \\
\hline$t 12-18: 1$ & $0.41^{\mathrm{a}}$ & $0.34^{\mathrm{b}}$ & $0.20^{\mathrm{c}}$ & $<0.01$ & 0.04 \\
\hline$t 13 / t 14-18: 1$ & $0.85^{\mathrm{a}}$ & $0.76^{\mathrm{a}}$ & $0.44^{\mathrm{b}}$ & 0.02 & 0.10 \\
\hline$t 15-18: 1$ & $0.23^{\mathrm{a}}$ & $0.22^{\mathrm{a}}$ & $0.13^{\mathrm{b}}$ & 0.02 & 0.03 \\
\hline$t 16-18: 1$ & $0.39^{\mathrm{a}}$ & $0.35^{\mathrm{a}}$ & $0.22^{\mathrm{b}}$ & $<0.01$ & 0.04 \\
\hline \multicolumn{6}{|l|}{ CLA isomers } \\
\hline$t 7 c 9$-CLA & $0.04^{\mathrm{a}}$ & $0.04^{\mathrm{a}}$ & $0.02^{\mathrm{b}}$ & $<0.01$ & 0.00 \\
\hline$t 12 t 14-\mathrm{CLA}$ & $0.04^{\mathrm{a}}$ & $0.03^{\mathrm{b}}$ & $0.02^{\mathrm{c}}$ & $<0.01$ & 0.00 \\
\hline$t 11 t 13$-CLA & $0.08^{\mathrm{a}}$ & $0.07^{\mathrm{a}}$ & $0.03^{\mathrm{b}}$ & $<0.01$ & 0.01 \\
\hline$t 10 t 12$-CLA & 0.01 & 0.01 & 0.01 & NS & 0.00 \\
\hline t9t11-CLA & $0.02^{\mathrm{a}}$ & $0.02^{\mathrm{a}}$ & $0.01^{\mathrm{b}}$ & $<0.01$ & 0.00 \\
\hline t8t10-CLA & 0.002 & 0.003 & 0.003 & NS & 0.00 \\
\hline$t 7 t 9-\mathrm{CLA}$ & 0.007 & 0.005 & 0.004 & NS & 0.00 \\
\hline
\end{tabular}

${ }^{\mathrm{a}-\mathrm{c}}$ Values in the same row not sharing a common superscript are significantly different $(P<0.05)$.

${ }^{1} t=$ trans; $c=$ cis; fatty acids were expressed as a percentage of total fatty acid methyl esters.

${ }^{2} \mathrm{G}$ = grazing; $\mathrm{ZG}=$ zero-grazing; $\mathrm{GS}=$ grass silage; plus $3 \mathrm{~kg}$ of concentrate to all the diets.

the least amount of intake of LA. An explanation is not readily apparent, other than possible components in the silage interfering with the biohydrogenation of RA to VA. However, it should be noted that the concentrations of RA in the rumen have little to do with the final concentrations of RA in milk. More than $80 \%$ of RA in milk has been shown to be derived from vaccenic acid via $\Delta^{9}$-desaturation (Griinari et al., 2000), and the concentrations of VA in the rumen were indeed proportional to the intake of LA in the diet.

In contrast to the rumen concentrations of RA, plasma RA concentrations (Table 7) were greater for $G$ than for GS, indicating that some degree of intestinal or hepatic desaturase activity had occurred with greater proportions of VA being converted to RA for $\mathrm{G}$ and ZG. Plasma RA concentrations were generally low $(<0.2 \%)$, but $\mathrm{G}$ had greater concentrations than GS. The other CLA isomers were only present in trace amounts including $t 7 c 9$-CLA $(0.01 \%)$ and $t 10 c 12$-CLA $(0.002 \%)$.

\section{Milk FA Composition}

Milk FA composition is presented in Table 8. Higher concentrations of total saturated FA were recorded for GS and ZG than for G and could be accounted for mainly by the difference in the concentrations of 16:0 and 14:0 and to a lesser extent by a difference in the concentrations of minor saturated FA such as iso and anteiso 13:0 and 15:0, and 19:0 and 20:0. There was no significant difference in the concentrations of shorter chain FA from 4:0 to 15:0 (except 6:0 and 8:0) and some of the longer chain saturated FA (22:0, 24:0) among the treatments. The sum of the branched chain FA (iso + anteiso) was less for GS than for G and ZG, which were similar. Phytanic acid was present only in trace amounts in milk lipids indicating some kind of barrier in the transfer of this isoprenoid FA into milk lipids. The total concentration of both n- 6 and n-3 PUFA ranged from 1.01 to 1.25 and 0.53 to 0.91 , respectively, with lesser concentrations for GS than for G or ZG (Table 8).

Greater concentrations of total $t-18: 1$, total transmonounsaturated fatty acids (MUFA), and total cis-MUFA were recorded in milk lipids for $\mathrm{G}$ and $\mathrm{ZG}$ compared with GS. The concentrations of $c 9-/ c 10-18: 1$ accounted for about $95 \%$ of the total $c-18: 1$ isomers across all treatments, and it was significantly different across the treatments with greater values recorded for G than for GS. 
Table 10. Predictive equations for milk rumenic acid (RA) yield (g/d) with substrate (18:2n-6 or 18:3n-3) intake variables from 2 sources: grass cuts $(\mathrm{GC})^{1}$ and herbage snips (HS) ${ }^{2}$

\begin{tabular}{lcc}
\hline Equation & $\mathrm{R}^{2}$ & $P$-value \\
\hline RA yield $\mathrm{g} / \mathrm{d}=0.35$ intake $18: 2 \mathrm{n}-6 \mathrm{HS}-14.62$ & 0.78 & $<0.01$ \\
RA yield $\mathrm{g} / \mathrm{d}=0.06$ intake $18: 3 \mathrm{n}-3 \mathrm{HS}-4.11$ & 0.79 & $<0.01$ \\
RA yield $\mathrm{g} / \mathrm{d}=0.05$ total substrate ${ }^{3}$ intake HS -5.74 & 0.79 & $<0.01$ \\
RA yield $\mathrm{g} / \mathrm{d}=0.40$ intake $18: 2 \mathrm{n}-6 \mathrm{GC}-15.93$ & 0.52 & $<0.01$ \\
RA yield $\mathrm{g} / \mathrm{d}=0.08$ intake $18: 3 \mathrm{n}-3 \mathrm{GC}-4.27$ & 0.49 & $<0.01$ \\
RA yield $\mathrm{g} / \mathrm{d}=0.06$ total substrate $^{3}$ intake $\mathrm{GC}-6.17$ & 0.49 & $<0.01$ \\
\hline
\end{tabular}

${ }^{1}$ Represents animal-wise substrate intake from all treatments $(\mathrm{n}=17)$ with values for grazing cows estimated from grass cuts (offered grass).

${ }^{2}$ Represents animal-wise substrate intake from all treatments $(n=17)$ with values for grazing cows estimated from herbage snips (consumed grass).

${ }^{3}$ Total substrate represents sum of 18:2n-6 + 18:3n-3.

Milk VA, t10-18:1, RA, and Desaturase Index. Among the $t-18: 1$ isomers, VA (t11-18:1) was most abundant followed by $t 13 / 14-18: 1$ in all treatments (Table 9). There was a significant difference in the concentration of milk VA among the treatments with concentrations being more than 4-fold and 3-fold greater for $\mathrm{G}$ and $\mathrm{ZG}$, respectively, compared with GS. This is the net result of the differences in substrate intake and the extent of ruminal biohydrogenation reflected in the concentrations of ruminal and plasma VA. The greater concentrations of VA for $\mathrm{G}$ than for ZG could be explained by the high intake of LA and LNA for G because of selective grazing of grass rich in these FA.

The concentration of the $t 10-18: 1$ isomer was less for GS than for G and ZG with no differences between the latter two. Furthermore, the $t 10$ - to $t 11-18: 1$ ratio was greater for GS than for G and ZG (Figure 1; Table 9). In the current study there was a decrease in milk fat yield among the treatments from G to ZG and GS (Table 2) that did not appear to be related to known milk fat depressing fatty acids such as t10c12-CLA (Griinari et al., 2000), t9c11-CLA (Perfield et al., 2007), or t10-18:1 (Griinari and Bauman, 1999). Therefore, the relationships between milk fat yield (dependent variable) and milk concentrations of $t 10-18: 1, t 10 c 12$-CLA, $t 7 c 9$-CLA, and $t 9 c 11$-CLA (independent variables) was investigated using stepwise regression analysis. None of the independent variables entered the model even at $P$ $<0.2$. However, repeating the regression analysis using the t10:t11-18:1 ratios in milk, plasma, and rumen

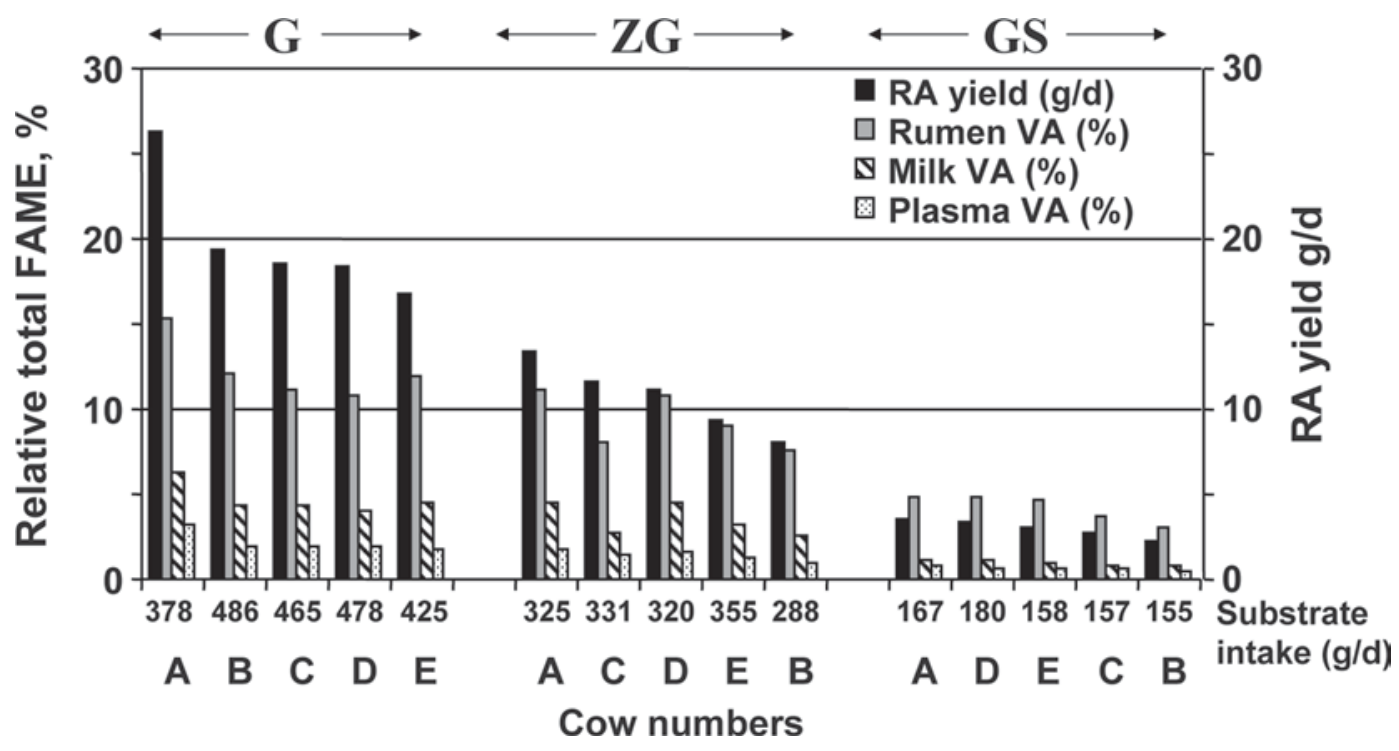

Figure 2. Animal- and treatment-wise rumenic acid (RA) yield (g/d), and ruminal vaccenic acid (VA), milk VA, and plasma VA concentrations. The relative concentration of VA (FAME = fatty acid methyl esters) is presented on the left y-axis, and RA yield is shown on the right y-axis. Substrate intake is the sum of 18:2n-6 and 18:3n-3 intake. $\mathrm{G}=$ grazing; $\mathrm{ZG}=$ zero-grazing; GS = grass silage; A to E represent different individual cows. 
Table 11. Stepwise regression analysis of a group of variables ${ }^{1}$ with milk rumenic acid yield $(\mathrm{g} / \mathrm{d})(\mathrm{n}=17$; $P \leq 0.09)$

\begin{tabular}{lccrc}
\hline Variable & Partial R $^{2}$ & Model $\mathrm{R}^{2}$ & $F$-value & $P$-value \\
\hline Plasma VA (a) & 0.9533 & 0.9533 & 265.63 & $<0.01$ \\
Intake 18:3n-3 (b) & 0.0319 & 0.9853 & 25.97 & $<0.01$ \\
Intake 18:2n-6 (c) & 0.0063 & 0.9915 & 8.17 & 0.02 \\
Equation: RA yield, g/d $=15.77+7.38 \mathrm{a}+0.14 \mathrm{~b}-0.67 \mathrm{c}$ & & & \\
\hline
\end{tabular}

${ }^{1}$ Independent variables considered for the model include intake of 18:2n-6, 18:3n-3, rumen vaccenic acid (VA), plasma VA, wet rumen fill, dry rumen fill, rumen $\mathrm{pH}$, and milk desaturase index.

revealed that $61 \%$ of the variability of milk fat yield was determined by the differences in milk $t 10: t 11-18: 1$ ratio $(P<0.01)$.

Higher concentrations of total CLA and RA were observed for $G$ than for GS (Tables 8 and 9). The concentrations of these isomers were less for $\mathrm{ZG}$ than for $\mathrm{G}$. Among the total CLA isomers RA was the predominant one, accounting for 86,83 , and $77 \%$ for treatments $\mathrm{G}$, $\mathrm{ZG}$, and GS, respectively. Other CLA isomers recorded in appreciable concentrations were $t 12 t 14-$, $t 11 c 13-$, $t 11 t 13-$, and $t 7 c 9-18: 2$ (Table 9). Considering the small proportion of LA compared with LNA in forage and the finding that biohydrogenation of LNA does not produce RA in the rumen, most of the milk RA yield in this study probably resulted from the differences in the supply of VA to the mammary tissue and subsequent mammary desaturase activity.

Although desaturase activity can be determined using ratios of 4 different pairs of FA (Peterson et al., 2002 ), the ratio $c 9-14: 1 / 14: 0$ has been reported to give a more accurate measure of mammary desaturase activity because 14:0 is synthesized de novo by the mammary tissue (Griinari et al., 2000; Corl et al., 2002; Lock and Garnsworthy, 2002). Desaturase index calculated based on ratio of milk $c 9-14: 1 / 14: 0$ was not different across the treatments (Table 8 ). Furthermore, milk desaturase index did not enter into the model when stepwise regression analysis of different variables influencing milk RA was done, indicating that mammary desaturase activity was not influenced by the differences in milk VA observed here. Although the present results do not support desaturase activity to be influenced by the treatments, there appears to be difference in desaturase activity among individual animals. The desaturase index of individual cows (based on the ratio $c 9-14: 1 / 14: 0$ ) ranged from 0.06 to 0.16 with a CV of $28 \%$, suggesting high variation among the cows within and between treatments. Part of this variation may be due to genetic differences among the cows (Mele et al., 2007).

Because there were no treatment effects on mammary desaturase index, the difference in milk RA response among the treatments can be related to the differences in LA and LNA intakes and the influence of diets on rumen environment. Lower concentrations of milk RA for GS was caused by lower DMI and lower intakes of LA and LNA compared with G or ZG. The higher response in milk $\mathrm{RA}$ observed for $\mathrm{G}$ relative to $\mathrm{ZG}$ could be partly due to the selective grazing (HS) by the grazing cows, which resulted in a higher intake of LA and LNA compared with that found in the offered grass (GC). Consistent with this, strong correlations were observed between milk RA yield $(\mathrm{g} / \mathrm{d})$ and intakes of LA and LNA quantified from HS compared with those quantified from GC (Table 10). Part of the differences in milk RA response between $\mathrm{G}$ and $\mathrm{ZG}$ could also be explained by the differences in rumen environment favoring greater ruminal VA concentrations.

\section{Efficiency of Milk RA Production}

Evaluation of the milk RA response based on the relative percentages of milk RA does not give a true picture of the efficiency of RA production when there are differences in the DMI, milk yield, fat yield, and LA and LNA intakes across the treatments. Therefore, we calculated RA yield per $100 \mathrm{~g}$ of total substrate $(\mathrm{LA}+\mathrm{LNA})$ intake (efficiency) to investigate if there were treatment differences on the efficiency of milk RA production. Efficiency of milk RA production was significantly different $(P<0.01$; SEM 0.17$)$ across the treatments, with higher values recorded for $\mathrm{G}(2.23)$ and ZG (1.50) than for GS (0.62) indicating that G cows were more efficient than ZG or GS cows because they were able to produce more RA yield per $100 \mathrm{~g}$ of total substrate intake. These differences in the efficiency of milk RA production could be caused by a combination of factors regulating ruminal VA production and its supply to the mammary tissue.

It was interesting to note that the efficiency of ruminal VA production followed the same trend as that of milk RA production. Rumen VA pool size, calculated as the product of rumen lipid content and rumen VA content, was greater $(P<0.01$; SEM 2.26) for $\mathrm{G}(45.3 \mathrm{~g})$ than for ZG $(28.5 \mathrm{~g})$ or GS $(7.7 \mathrm{~g})$. Rumen VA yield/100 g of total substrate intake (efficiency) was greater $(P<$ 0.01; SEM 0.74) for G (10.3 g) than for ZG (8.9 g) or 
GS (4.8 g), indicating that there was some influence of diet on rumen environment favoring greater production of VA by G cows.

Dietary influence on rumen environment and milk RA yield is clearly evident when data from individual animals were considered (Figure 2). For instance, cow A produced $26 \mathrm{~g}$ of $\mathrm{RA} / \mathrm{d}$ with a total substrate (LA + LNA) intake of $378 \mathrm{~g} / \mathrm{d}$ on treatment $\mathrm{G}$ and only 13 $\mathrm{g}$ of RA/d with a total substrate intake of $325 \mathrm{~g} / \mathrm{d}$ on treatment ZG (a $50 \%$ decrease in RA yield for a $15 \%$ decrease in substrate intake compared with $G$ ). When this cow was on treatment GS, she produced only 3.5 $\mathrm{g} / \mathrm{d}$ of RA by consuming $167 \mathrm{~g} / \mathrm{d}$ total substrate (a $90 \%$ decrease in RA yield for a $55 \%$ decrease in substrate intake compared with $\mathrm{G}$ ). On the other hand, cow E produced $17 \mathrm{~g}$ of RA/d by consuming $425 \mathrm{~g} / \mathrm{d}$ of total substrate on treatment $\mathrm{G}$, and only $9 \mathrm{~g}$ of RA/d with a total substrate intake of $355 \mathrm{~g} / \mathrm{d}$ on treatment ZG (a $50 \%$ decrease in RA yield for a $16 \%$ decrease in intake). On treatment GS, cow E produced $3 \mathrm{~g}$ of RA/d with a total substrate intake of $158 \mathrm{~g} / \mathrm{d}$ resulting in a $80 \%$ decrease in RA yield for a $60 \%$ decrease in substrate intake compared with G. These results clearly demonstrated that the intake of dietary substrates was not the only factor controlling milk RA production.

A stepwise regression analysis was used to identify the variables that most influenced milk RA yield. The relationship between milk RA yield and source of substrate [GC (offered) or HS (consumed)] for G cows was first investigated to find out which of these two are strongly related to milk RA yield using the REG procedure of SAS. Evaluation of the equations for the prediction of RA yield with single factors [LA intake (from HS), LNA intake (from HS), total substrate intake (LA + LNA from HS), LA intake (from GC), LNA intake (from GC), and total substrate intake (LA + LNA from GC)] revealed that the substrate intake quantified from HS was strongly correlated with milk RA yield compared with the substrate intake estimated from GC (Table 10). Subsequently the substrate intake variables LA and LNA estimated from HS for G cows together with LA and LNA from ZG and GS were utilized in a stepwise regression analysis with multiple factors using the STEPWISE procedure of SAS. The threshold value to keep a term in the model was $P \leq 0.09$.

Stepwise regression analysis using the variables LA intake, LNA intake, forage DMI, total DMI, milk yield, milk fat yield, and milk desaturase index revealed that $79.4 \%$ of the variability in milk RA yield was determined by the differences in intake of LNA $(P<0.01)$, and only about $6.7 \%$ of the variation was influenced by forage DMI $(P=0.02)$. These results are in agreement with those of Bargo et al. (2006) who reported that LNA intake contributed the most (41\%) to the variability in milk CLA. When the variables VA and RA from rumen and plasma, milk VA, rumen fill (wet and dry), and rumen $\mathrm{pH}$ were also added to the model, $95.3 \%$ of variability in milk RA yield was determined by the differences in plasma VA concentrations (Table 11). The variables subsequently selected in the model include LNA intake and LA intake, although their contribution in improving the model $\mathrm{R}^{2}$ was very small. Milk desaturase index did not enter into the model even at a significance level of 0.2 , indicating that it was not influenced by the differences in milk VA in this study. Regression analysis using plasma VA as a dependent variable and total DMI, forage DMI, LA intake, LNA intake, total substrate (LA + LNA) intake, ruminal LA, ruminal LNA, ruminal VA, rumen $\mathrm{pH}$, and rumen fill (wet and dry) at $P \leq 0.09$ revealed that $93 \%$ of the variability in plasma VA was determined by ruminal VA $(P<0.01)$. Wet rumen fill subsequently entered in the model; however, it improved the model $\mathrm{R}^{2}$ by only an additional $2 \%(P=0.08)$. Repeating the analysis with the same independent variables listed above but with ruminal VA as dependent variable revealed that $75 \%$ of the variability in ruminal VA was determined by total substrate $(\mathrm{LA}+\mathrm{LNA})$ intake $(P<0.01) ; 7 \%$ by forage DMI $(P=0.05) ; 5.7 \%$ by LNA intake $(P=$ $0.04)$; and dry rumen fill by an additional $3.8 \%(P=$ $0.05)$.

The overall findings suggest that approximately $75 \%$ of the variability in milk RA yield in the current study can be explained by the variation in total substrate intake. The rest of the variability is due to differences in efficiency of milk RA production that is influenced by the interplay of various factors regulating ruminal VA production and its supply to the mammary tissue. These factors include (but are not limited to) differences in DMI, rumen fill, rumen $\mathrm{pH}$, rumen bacterial populations, intake characteristics (e.g., pattern of chewing, rumination, saliva production), and digesta kinetics favoring increased ruminal VA production or biohydrogenation inhibition and differences in assimilation and flow of biohydrogenation intermediates to the mammary tissue. Further studies are required to investigate the role of digesta kinetics (operating at the rumen as well as the small intestine), animal genetics, and other factors influencing absorption of the biohydrogenation intermediates and contributing to the differences in plasma VA and in turn to the variability in milk RA production.

\section{ACKNOWLEDGMENTS}

The authors acknowledge the financial support of Natural Sciences and Engineering Research Council of Canada, Alberta Milk, Irish Dairy Levy Funds, Irish 
Government (National Development Plan 2000-2006), and EU Project QLK1-2002-02362. We also thank Laki Goonewardene, adjunct professor at the University of Alberta (Edmonton) for statistical advice; Robert J. Forster, research scientist at Agriculture and Agri-Food Canada (Lethbridge Research Centre, Lethbridge) for helpful advice during the study; and Emer Kennedy (Teagasc, Moorepark, Ireland) for assistance in the management of grazing cows. The technical assistance of Naomi Beswick (University of Alberta, Edmonton, Alberta, Canada), Marta Hernandez (Agriculture and Agri-Food Canada, Guelph, Ontario, Canada), and Flor Flynn, Jim Nash, Michael Feeney, and Norann Galvin (Teagasc, Moorepark, Ireland) is gratefully acknowledged. R. Mohammed was the recipient of Walsh Fellowship sponsored by Teagasc.

\section{REFERENCES}

Bargo, F., J. E. Delahoy, G. F. Schroeder, L. H. Baumgard, and L. D. Muller. 2006. Supplementing total mixed rations with pasture increase the content of conjugated linoleic acid in milk. Anim. Feed Sci. Technol. 131:226-240.

Bauman, D. E., L. H. Baumgard, B. A. Corl, and J. M. Griinari. 1999. Biosynthesis of conjugated linoleic acid in ruminants. Proc. Am. Soc. Anim. Sci. 1999:1-15.

Bell, J. A., J. M. Griinari, and J. J. Kennelly. 2006. Effect of safflower oil, flaxseed oil, monensin, and vitamin $\mathrm{E}$ on concentrations of conjugated linoleic acid in bovine milk fat. J. Dairy Sci. 89:733748.

Boufaïed, H., P. Y. Chouinard, G. F. Tremblay, H. V. Petit, R. Michaud, and G. Bĕlanger. 2003a. Fatty acids in forages. I. Factors affecting concentrations. Can. J. Anim. Sci. 83:501-511.

Boufaïed, H., P. Y. Chouinard, G. F. Tremblay, H. V. Petit, R Michaud, and G. Bĕlanger. 2003b. Fatty acids in forages. II. In vitro ruminal biohydrogenation of linolenic and linoleic acids from timothy. Can. J. Anim. Sci. 83:513-522.

Chaves, A. V., and A. Boudon. 2005. Effects of rumen fill on intake and milk production in dairy cows fed perennial ryegrass. Proceedings of a satellite workshop of the XXth International Grassland Congress, Cork, Ireland. Wageningen Acad. Publ., Wageningen, the Netherlands.

Chilliard, Y., and A. Ferlay. 2004. Dietary lipids and forages interactions on cow and goat milk fatty acid composition and sensory properties. Reprod. Nutr. Dev. 44:467-492.

Corl, B. A., L. H. Baumgard, M. J. Griinari, P. Delmonte, K. M. Morehouse, M. P. Yurawecz, and D. E. Bauman. 2002. Trans7,cis-9 CLA is synthesized endogenously by $\Delta^{9}$-desaturase in dairy cows. Lipids 37:681-688.

Cruz-Hernandez, C., Z. Deng, J. Zhou, A. R. Hill, M. P. Yurawecz, P. Delmonte, M. M. Mossoba, M. E. R. Dugan, and J. K. G. Kramer. 2004. Methods for analysis of conjugated linoleic acids and trans-18:1 isomers in dairy fats by using a combination of gas chromatography, silver-ion thin-layer chromatography/gas chromatography, and silver-ion liquid chromatography. J. AOAC Int. 87:545-562.

Cruz-Hernandez, C., J. K. G. Kramer, J. J. Kennelly, D. R. Glimm, B. M. Sorensen, E. K. Okine, L. A. Goonewardene, and R. J. Weselake. 2007. Evaluating the conjugated linoleic acid and trans 18:1 isomers in milk fat of dairy cows fed increasing amounts of sunflower oil and a constant level of fish oil. J. Dairy Sci. 90:3786-3801.

Cruz-Hernandez, C., J. K. G. Kramer, J. Kraft, V. Santercole, M. Or-Rashid, Z. Deng, M. E. R. Dugan, P. Delmonte, and M. P. Yurawecz. 2006. Systematic analysis of trans and conjugated linoleic acids in the milk and meat of ruminants. Pages 45-93 in Advances in Conjugated Linoleic Acid Research. Vol. 3. M. P. Yurawecz, J. K. G. Kramer, O. Gudmundsen, M. W. Pariza and S. Banni, ed. Am. Oil Chem. Soc., Champaign, IL.

Demarquilly, C. 1973. Composition chimique caracteristiques fermentaires, digestibilite et quantite ingeree des ensilages de fourrages. Modifications par rapport au fourrage vert initial. Ann. Zootech. 22:1-35.

Elgersma, A., S. Tamminga, and G. Ellen. 2003. Comparison of the effects of grazing versus stall-feeding of cut grass on milk fatty acid composition of dairy cows. Proc. Int. Occ. Symp. European Grassland Federation, Pleven, Bulgaria, May 2003. Grassl. Sci. Europe 8:271-274.

Faruque, A. J. M. O., B. D. W. Jarvis, and J. C. Hawke. 1974. Studies on rumen metabolism. IX. Contribution of plant lipases to the release of free fatty acids in the rumen. J. Sci. Food Agric. $25: 1313-1328$

Fontenot, J. P., and R. E. Blaser. 1965. Symposium on factors influencing the voluntary intake of herbage by ruminants: Selection and intake by grazing animals. J. Anim. Sci. 24:1202-1208.

Griinari, J. M., and D. E. Bauman. 1999. Biosynthesis of conjugated linoleic acid and its incorporation into meat and milk in ruminants. Pages 180-200 in Advances in Conjugated Linoleic Acid Research. Vol. 1. M. P. Yurawecz, M. M. Mossoba, J. K. G. Kramer, M. W Pariza and G. J. Nelson, ed. Am. Oil Chem. Soc., Champaign, IL.

Griinari, J. M., B. A. Corl, S. H. Lacy, P. Y. Chouinard, K. V. V. Nurmela, and D. E. Bauman. 2000. Conjugated linoleic acid is synthesized endogenously in lactating dairy cows by $\Delta^{9}$-desaturase. J. Nutr. 130:2285-2291

Hardison, W. A., J. T. Reid, C. M. Martin, and P. G. Woolfolk. 1954. Degree of herbage selection by grazing cattle. J. Dairy Sci. 37:89102.

Harfoot, C. G., R. C. Noble, and J. H. Moore. 1973. Factors influencing the extent of biohydrogenation of linoleic acid by rumen microorganisms in vitro. J. Sci. Food Agric. 24:961-970.

Harris, C. E., W. F. Raymond, and R. F. Wilson. 1966. The voluntary intake of silage. Pages 218-222 in Proc. 10th Int. Grassl. Congr., section-2. Finnish Grassland Association, Helsinki, Finland.

Jenkins, T. C., R. J. Wallace, P. J. Moate, and E. E. Mosley. 2008 Recent advances in biohydrogenation of unsaturated fatty acids within the rumen microbial ecosystem. J. Anim. Sci. 86:397412.

Johnston-Wallace, D. B. 1937. The influence of grazing management and plant associations on the chemical composition of pasture plants. J. Am. Soc. Agron. 29:441-455.

Johnston-Wallace, D. B., and K. Kennedy. 1944. Grazing management practices and their relationship to the behavior and grazing habits of cattle. J. Agric. Sci. 34:190.

Kalscheur, K. F., B. B. Teter, L. S. Piperova, and R. A. Erdman 1997. Effect of dietary forage concentration and buffer addition on duodenal flow of trans-C18:1 fatty acids and milk fat production in dairy cows. J. Dairy Sci. 80:2104-2114.

Keady, T. W. J., J. J. Murphy, and D. Harrington. 1995. The effects of ensiling on dry matter intake and milk production by lactating dairy cattle given forage as the sole feed. Grass Forage Sci. $51: 131-141$

Kennedy, E., M. O'Donovan, J. P. Murphy, L. Delaby, and F. O'Mara 2005. Effects of grass pasture and concentrate-based feeding systems for spring-calving dairy cows in early spring on performance during lactation. Grass Forage Sci. 60:310-318.

Kennedy, E., M. O'Donovan, J. P. Murphy, F. P. O'Mara, and L. Delaby. 2006. The effect of initial spring grazing date and subsequent stocking rate on the grazing management, grass dry matter intake and milk production of dairy cows in summer. Grass Forage Sci. 61:375-384.

Kraft, J., J. K. G. Kramer, F. Schoene, J. R. Chambers, and G. Jahreis. 2008. Extensive analysis of long-chain polyunsaturated fatty acids, CLA, trans-18:1 isomers and plasmalogenic lipids in different retail beef types. J. Agric. Food Chem. 56:4775-4782. 
Kramer, J. K. G., M. Hernandez, C. Cruz-Hernandez, J. Kraft, and M. E. R. Dugan. 2008. Combining results of two GC separations partly achieves determination of all cis and trans 16:1, 18:1, 18:2 and 18:3 except CLA isomers of milk fat as demonstrated using Ag-ion SPE fractionation. Lipids 43:259-273.

Lee, M. R. F., S. A. Huws, N. D. Scollan, and R. J. Dewhurst. 2007. Effects of fatty acid oxidation products (green odor) on rumen bacterial populations and lipid metabolism in vitro. J. Dairy Sci. 90:3874-3882.

Leiber, F., M. Kreuzer, D. Nigg, H. Wettstein, and M. R. L. Scheeder. 2005. A study on the causes for the elevated n-3 fatty acids in cows' milk of alpine origin. Lipids 40:191-202.

Lesperance, A. L., V. R. Bohman, and D. W. Marble. 1960. Development of techniques for evaluating grazed forage. J. Dairy Sci. 43:682-689.

Lock, A. L., and P. C. Garnsworthy. 2002. Independent effects of dietary linoleic and linolenic fatty acids on the conjugated linoleic acid content of cow's milk. Anim. Sci. 74:163-176.

Lough, A. K., and L. J. Anderson. 1973. Effect of ensilage on the lipids of pasture grasses. Proc. Nutr. Soc. 32:61A.

Martin, S. A., and T. C. Jenkins. 2002. Factors affecting conjugated linoleic acid and trans-C18:1 fatty acid production by mixed ruminal bacteria. J. Anim. Sci. 80:3347-3352.

Mayes, R.W., C. S. Lamb, and P. M. Colgrave. 1986. The use of dosed and herbage n-alkanes as markers for the determination of herbage intake. J. Agric. Sci. Camb. 107:161-170.

McEvoy, M., E. Kennedy, J. P. Murphy, T. M. Boland, L. Delaby, and M. O'Donovan. 2008. The effect of herbage allowance and concentrate supplementation on milk production performance and dry matter intake of spring-calving dairy cows in early lactation. J. Dairy Sci. 91:1258-1269

Mele, M., G. Conte, B. Castiglioni, S. Chessa, N. P. P. Macciotta, A. Serra, A. Buccioni, G. Pagnacco, and P. Secchiari. 2007. Stearoylcoenzyme A desaturase gene polymorphism and milk fatty acid composition in Italian Holsteins. J. Dairy Sci. 90:4458-4465.

Morgan, D. J., G. Stakelum, and J. O'Dwyer. 1989. Modified neutral detergent cellulose digestibility procedure for use with the "Fibertec" system. Irish J. Agric. Res. 28:91-92.

Offer, N. W. 2002. Effects of cutting and ensiling grass on levels of CLA in bovine milk. Pages 16-17 in Proc. 13th Int. Silage Conf., Auchincruive, Scotland. L. M. Gechie and C. Thomas, ed. Scottish Agricultural College, UK.

Or-Rashid, M. M., J. K. G. Kramer, M. A. Wood, and B. W. McBride 2008. Supplemental algal meal alters the ruminal trans-18:1 fatty acid and conjugated linoleic acid composition in cattle. J. Anim. Sci. 86:187-196

Paetzold, H., and W. Stottmeister. 1966. Grazing versus silage for dairy cows in Northern Germany. Pages 155-159 in Proc. 10th Int. Grassl. Congr. Finnish Grassland Association, Helsinki, Finland.
Perfield, J. W. II, A. L. Lock, J. M. Griinari, A. Sæbø, P. Delmonte, D. A. Dwyer, and D. E. Bauman. 2007. Trans-9, cis-11 conjugated linoleic acid reduces milk fat synthesis in lactating dairy cows. J. Dairy Sci. 90:2211-2218.

Peterson, D. G., J. A. Kelsey, and D. E. Bauman. 2002. Analysis of variation in cis-9, trans-11 conjugated linoleic acid (CLA) in milk fat of dairy cows. J. Dairy Sci. 85:2164-2172.

Qiu, X., M. L. Eastridge, K. E. Griswold, and J. L. Firkins. 2004. Effects of substrate, passage rate, and $\mathrm{pH}$ in continuous culture on flows of conjugated linoleic acid and trans $\mathrm{C}_{18: 1}$. J. Dairy Sci. 87:3473-3479.

Ranfft, K. 1973. Gas chromatography of short chain fatty acids. Arch. Tierernahr. 23:343-352.

Runcie, K. V. 1960. The utilization of grass by strip grazing and zero grazing with dairy cows. Pages $644-648$ in Proc. 8th Int. Grassl. Congr. British Grassland Society, Hurley, UK.

Short, E. I. 1954. The estimation of total nitrogen using the Conway micro-diffusion cell. J. Clin. Pathol. 7:81-83.

Steele, W., and R. C. Noble. 1983. Changes in lipid composition of grass during ensiling with or without added fat or oil. Proc. Nutr. Soc. $43: 51 \mathrm{~A}$.

Thomas, H. 1986. The role of polyunsaturated fatty acids in senescence. J. Plant Physiol. 123:97-105.

Troegeler-Meynadier, A., M. C. Nicot, C. Bayourthe, R. Moncoulon, and F. Enjalbert. 2003. Effects of $\mathrm{pH}$ and concentrations of linoleic and linolenic acids on extent and intermediates of ruminal biohydrogenation in vitro. J. Dairy Sci. 86:4054-4063.

Urban, B., and J. P. Caudal. 1990. Herbometre automatise (automatic platemeter). Pages 57-59 in Les journees de la mesure. Electronique, informatique, automatique, Port Leucate, France. INRA, Paris, France.

Van Nevel, C. J., and D. I. Demeyer. 1996. Influence of $\mathrm{pH}$ on lipolysis and biohydrogenation of soybean oil by rumen contents in vitro. Reprod. Nutr. Dev. 36:53-63.

Van Soest, P. J., J. B. Robertson, and B. A. Lewis. 1991. Methods for dietary fiber, neutral detergent fiber, and nonstarch polysaccharides in relation to animal nutrition. J. Dairy Sci. 74:3583-3597.

Vlaeminck, B., V. Fievez, A. R. J. Cabrita, A. J. M. Fonseca, and R. J. Dewhurst. 2006a. Factors affecting odd- and branched-chain fatty acids in milk: A review. Anim. Feed Sci. Technol. 131:389-417.

Vlaeminck, B., V. Fievez, S. Tamminga, R. J. Dewhurst, A. van Vuuren, D. De Brabander, and D. Demeyer. 2006b. Milk odd- and branched-chain fatty acids in relation to the rumen fermentation pattern. J. Dairy Sci. 89:3954-3964.

Younge, B. A., J. J. Murphy, and M. Rath. 2004. Nutrient metabolism in the rumen and milk production in cows fed on grass-silage and fresh grass based diets. Livest. Prod. Sci. 88:43-54. 